\title{
The curse of extremes: generalist career experience and CEO initial compensation
}

Article

Accepted Version

Mueller, P. E.M., Georgakakis, D., Greve, P., Peck, S. and Ruigrok, W. (2021) The curse of extremes: generalist career experience and CEO initial compensation. Journal of Management, 47 (8). pp. 1977-2007. ISSN 1557-1211 doi: https://doi.org/10.1177/0149206320922308 Available at https://centaur.reading.ac.uk/89891/

It is advisable to refer to the publisher's version if you intend to cite from the work. See Guidance on citing.

To link to this article DOI: http://dx.doi.org/10.1177/0149206320922308

Publisher: Sage

All outputs in CentAUR are protected by Intellectual Property Rights law, including copyright law. Copyright and IPR is retained by the creators or other copyright holders. Terms and conditions for use of this material are defined in the End User Agreement.

\section{www.reading.ac.uk/centaur}

\section{CentAUR}

Central Archive at the University of Reading 
Reading's research outputs online 
THE CURSE OF EXTREMES: GENERALIST CAREER EXPERIENCE

\title{
AND CEO INITIAL COMPENSATION
}

\author{
Philipp Mueller \\ University of St Gallen \\ Research Institute for International Management \\ Dufourstrasse 40a \\ 9000 St Gallen, Switzerland \\ E-Mail: philipp.mueller@ unisg.ch \\ Dimitrios Georgakakis* \\ University of St Gallen \\ Research Institute for International Management \\ Dufourstrasse 40a \\ 9000 St Gallen, Switzerland \\ E-Mail: dimitrios.georgakakis@unisg.ch
}

Peder Greve

Henley Business School

University of Reading

Greenlands, Henley-on-Thames, RG9 3AU, UK

E-Mail: peder.greve@henley.ac.uk

\section{Simon Peck}

Case Western Reverse University

Weatherhead School of Management

Peter P. Lewis Building 232, Cleveland

E-Mail: simon.peck@case.edu

\section{Winfried Ruigrok}

University of St Gallen

Research Institute for International Management

Dufourstrasse 40a

9000 St Gallen, Switzerland

E-Mail: winfried.ruigrok@ unisg.ch

\section{*Corresponding author}

${ }^{\text {a }}$ Supplemental material for this article is available at http://xxx.sagepub.com/supplemental

Acknowledgements: We gratefully thank Gerard Hodgkinson and three anonymous reviewers for their comments and suggestions. We also thank Bert Cannella, Tine Buyl, and Georg Guttmann for their comments in earlier drafts. 


\title{
THE CURSE OF EXTREMES: GENERALIST CAREER EXPERIENCE AND CEO INITIAL COMPENSATION
}

\begin{abstract}
Studies argue that generalist CEOs are more valued by the market for executive labor and receive higher initial compensation. Challenging this prevailing assumption, we acknowledge the drawbacks of extensive career mobility and predict an inverted U-shape relationship between $\mathrm{CEO}$ generalist career experience and $\mathrm{CEO}$ initial compensation. Integrating the generalism and specialization views of human capital, we postulate that at an initial level, the acquisition of experience-breadth from different firms and industries enables CEOs to broaden their knowledge-base, obtain a variety of skills, and thus increase their labor-market value and initial compensation. After a threshold, however, the accumulation of extensive levels of career generalism through frequent job-hopping across firm and industry contexts gradually causes a lack of experience-depth and insufficient career specialization - thereby triggering lower CEO market-value and initial pay. Data from 197 CEO appointments in large publicly traded firms support our predictions. Our results also show that the observed inverted U-shape relationship varies with factors nested at different layers of context - highlighting the contingent nature of this area of research.
\end{abstract}

Keywords: CEO career experience; CEO compensation; Human capital; Curvilinearity; Executive job demands 


\section{INTRODUCTION}

The increase in CEO compensation has sparked an intense debate about the determinants of this trend (Devers, Cannella, Reilly \& Yoder, 2007; van Essen, Heugens, Otten, \& van Oosterhout, 2012; van Essen, Otten \& Carberry, 2015). Indeed, scholars have recognized that "few topics on strategic leadership generate the same degree of controversy" as the antecedents of CEO pay (Finkelstein, Hambrick, \& Cannella, 2009: 291). In understanding the determinants of CEO compensation, researchers have focused on CEO human capital and career backgrounds (Falato, Li \& Milbourn, 2015; Murphy \& Zabojnik, 2004), arguing that corporate leaders with broad-general career experience receive different compensation packages at the time of appointment compared to their narrow-specialist counterparts (Custodio, Ferreira, \& Matos, 2013; Frydman, 2019; Merluzzi \& Phillips, 2016). Examining the human capital antecedents of CEO initial pay is important, as it helps us to understand the skills that firms value most when they select corporate leaders (Chen, 2015; Fulmer, 2009; Graffin, Hubbard, Christensen, \& Lee, 2020). Yet, while research in this area has gained momentum, the degree to which generalist versus specialist human capital results in higher CEO initial pay is not clearly established in the literature.

On the one hand, some studies take the generalism view to argue that the accumulation of experience-breadth from different firm and industry contexts enhances a CEO's information processing ability (Dragoni, Oh, Vankatwyk, \& Tesluk, 2011), and promotes increasing CEO market value and initial compensation (Custodio et al., 2013; Frydman, 2019). Conversely, however, another research stream draws on the specialization view to highlight the disadvantages of accumulating diverse career experience (Kang \& Snell, 2009). According to this perspective, career mobility across firm and industry contexts comes at the expense of sacrificing career specialization (Mishra, 2014) - often resulting in superficial knowledge from a variety of areas without mastery in any of them (Zuckerman, Kim, Ukanwa, \& Rittmann, 2003). Individuals who engage in high career mobility are therefore more likely to face the 
“paradox of breadth" (Kacperczyk \& Younkin, 2017: 731), signal insufficient career focus to potential employers, and realize lower economic returns (Acemoglu \& Pischke, 1999; Simmons \& Berri, 2009). Such theoretical and empirical controversy calls for a more detailed conceptualization over whether, and under what conditions, broad-general as opposed to narrow-specialized career backgrounds associate with higher (or lower) CEO market value and initial compensation.

In this study, we add to this area of research. Integrating the seemingly opposing arguments of the generalism and specialization views, we postulate that the relationship between CEO generalist career experience and CEO initial compensation is neither positive nor negative per se, but rather inverted curvilinear. Initially, the accumulation of experience breadth from various firms and industries enables CEOs to broaden their knowledge-base (Karaevli \& Hall, 2006), enhance their information processing ability (Custodio, Ferreira, \& Matos, 2019), and thereby realize the market value and initial pay advantages underscored by the generalism view. After a threshold, however, the accumulation of extensive levels of varied career experience comes with a relative loss of specialization, gradually causing a lack of experience depth. This lack of specialization that occurs toward excessive levels of generalist experience will - ceteris paribus - lead to lower CEO market value and initial compensation.

Further, taking a contingency perspective on the value of CEO human capital (Combs \& Skill, 2003) and drawing on the notion of 'context-induced' executive job demands (Chen, 2015; Hambrick, Finkelstein, \& Mooney, 2005; Henderson \& Fredrickson, 1996), we also suggest that the proposed inverted U-shape relationship varies with a set of contingencies - the firm's degree of diversification (Henderson \& Fredrickson, 1996), the organization's prior performance (Chen, 2015), and the level of industry complexity (Datta, Guthrie, \& Rajagopalan, 2002). Scholars have argued that these factors relate to the 'complexity-driven' and 'performance-driven' executive job demands (Hambrick et al., 2005) and affect how CEOs are compensated (Henderson \& Fredrickson, 1996). Extending this line of reasoning, we 
examine how CEOs with different career profiles are more (or less) likely to realize higher initial pay returns when they are appointed by firms facing different conditions. Given that diverse experience is valued more in contexts with high information processing requirements (Hambrick et al., 2005) - we suggest that generalist CEOs will be more likely to bid up their price, and receive higher initial pay, when they are appointed in such contexts. In this regard, we respond to the call for more integrative studies on CEOs (Busenbark, Krause, Boivie \& Graffin, 2016) - by proposing a framework that simultaneously incorporates the person (CEO human capital) and the environment (firm diversification, past performance, and industry complexity) to explain the complex link between CEO career background and initial CEO pay.

It is useful to make two clarifications about our focus and analyses on CEO compensation. First, we focus on initial pay (i.e., the pay a CEO receives in the first complete fiscal year of appointment) to reduce the effects of managerial power accumulated over a CEO's tenure, which may mask the effects of human capital credentials on CEO compensation (see also: Chen, 2015; Falato et al., 2015; Graffin et al., 2020). Second, acknowledging that CEO selection preferences and recruitment processes vary among organizations and between contexts (Datta et al., 2002; Phillips \& Gully, 2015), we account for various confounding factors that may concurrently influence CEO selection and CEO initial pay.

Our study makes three key contributions to the literature on CEO initial compensation and human capital. First, it challenges prevailing assumptions about the value of CEO generalist versus specialist career experience. We demonstrate that - ceteris paribus 'penalties in human-capital value' are likely to occur not only for newly appointed CEOs who have excessively specialized throughout their careers and thus lack generic skills (Custodio et al., 2013; Merluzzi \& Philipps, 2016; Murphy \& Zabojnik, 2004), but also for those who have excessively diversified their human capital by engaging in frequent career mobility across firms and industries. In this regard, our study offers insights that are relevant not only for executives who make career choices with the aim of optimizing their labor market value (Datta et al., 
2002), but also for firms that establish programs for selecting and developing top managers with valuable human capital.

Second, our study advances research on the effects of context-driven job demands on CEO initial compensation (Hambrick et al., 2005). Research shows that CEOs appointed by firms facing greater informational demands are paid higher at the time of selection - as a premium for the managerial challenges they are expected to face after appointment (Chen, 2015; Combs \& Skill, 2003). Our work adds to this area of research by revealing that the ceteris paribus declining pay effects toward high levels of generalism vary under conditions of different job demands (Hambrick et al., 2005; Henderson \& Fredrickson, 1996). Overall, our study challenges the prevailing 'the more generalist the better' logic. It reveals that there may be a 'curse of extremes', whereby extensively high and extensively low levels of CEO generalism promote lower initial pay (relative to moderate levels) across a range of conditions.

Finally, our work offers practical implications regarding the notion of boundaryless career orientation - which has often been described as an ideal path for executives to increase their labor market value (Mansaramani, 2012). Our work confirms that there is, indeed, a 'dark side of contemporary careers' (Baruch \& Vardi, 2016: 355), whereby executives who engage in excessive career mobility realize lower initial compensation. To this end, our work has practical implications for executive career development.

\section{THEORY AND HYPOTHESES}

Strategic leadership research has long been concerned with understanding the factors that drive firms to select and compensate executives based on their skills and career experiences (Finkelstein et al., 2009). A key trend in this field of research is the shift from the 'traditional' organizational career path, to the rise of 'protean and boundaryless' careers (Briscoe, Hall, \& DeMuth, 2006: 30). Empirical evidence shows that, compared to some decades before, CEOs today have spent on average less time in their current firms and often possess experience from 
a variety of institutional contexts (Murphy \& Zabojnik, 2004). From a strategic staffing perspective, the observed lower average of CEO tenure implies that firms tend to more frequently select corporate leaders with generalist human capital (Custodio, Ferreira, \& Matos, 2019). Meanwhile, scholars stress that there are still factors that motivate executives to follow traditional career paths (Baruch \& Vardi, 2016) and develop specialized career profiles.

At the time of CEO selection, firms compete for executive talent, and attempt to recruit individuals with an abundance of human capital. Given its complex nature, however, the selection of a new CEO is affected by several aspects - including whether the firm can attract a wide pool of candidates and select the optimal one (Phillips \& Gully, 2015). Beyond why firms select one CEO over another candidate, however, a number of studies have examined CEO initial compensation after appointment - by observing pay differences between CEOs selected by firms that face different conditions (Bragaw \& Misangyi, 2017; Chen, 2015; Falato et al., 2015). While studies on CEO selection help to explain why the firm appointed a CEO vis-à-vis another candidate, studies on CEO initial compensation reveal 'how much' a CEO's human capital is valued across different contexts. According to Merluzzi and Phillips (2016: 97), initial pay provides a direct economic determinant of the amount that an "employer is willing to pay in order to obtain the employee" - and thus can provide insights on how CEOs with different career backgrounds are valued by firms facing different conditions.

In examining the relationship between career experience and initial pay, scholars have distinguished between two types of career-investments: (a) investments in acquiring experience-breadth and generic skills (i.e., career generalism) and (b) investments in developing experience-depth (i.e., career specialization) (Ferguson \& Hasan, 2013). In particular, some studies have examined how inter-firm and inter-industry mobility helps individuals to broaden their knowledge repertoires, acquire a variety of skills from different contexts, and hence increase their overall labor-market value and compensation (Custodio et al., 2013). Yet, other studies have underscored the importance of career specialization - 
acknowledging that specialized-knowledge is a 'net benefit' that associates with higher remuneration returns (Ferguson \& Hasan, 2013; Munasinghe \& Sigman, 2004). This theoretical controversy has led to calls for investigating the trade-off between generalism and specialization in executive careers (Falato et al., 2015; Frydman, 2019; Lazear, 2004; Sullivan \& Baruch, 2009).

In this study we contribute to this area of research. We postulate that the notions of generalism and specialization should be considered in parallel - as they jointly explain the economic value of a CEO's career background. On the one hand, executives with extensive levels of specialization possess experience that is limited within a given domain of expertise, and thus lack the variety of skills that is essential for the effective management of large and complex organizations (Custodio et al., 2013; Murphy \& Zabojnik, 2004). Conversely, executives with extensive levels of generalism often signal insufficient career-focus and expertise to potential employers (Zuckerman et al, 2003). While generalism equips executives with varied human capital and generic skills (Custodio et al., 2013), extensive career mobility demonstrates a lack of career focus (Kacperczyk \& Younkin, 2017) and is subject to the negative effects of continuous 'job hopping' across employers and contexts (Munasinghe \& Sigman, 2004). Reconciling these seemingly opposing streams of thought, we contend that generalism and specialization represent a trade-off - where CEOs at relatively moderate levels of the generalist experience continuum (i.e., those who attain a relative balance of generalism and specialization) realize higher initial pay returns compared to those at the extremes (i.e., extensive generalists and extensive specialists). Our logic therefore implies that the acquisition of generalist career experience is only beneficial for a CEO's value up to a threshold - after which the specialization costs of excessive career mobility start to become dominant and outweigh the benefits of additional generalism, gradually lowering new CEO value and initial compensation. 
Further, drawing on the literature of executive job demands (Hambrick et al., 2005; Henderson \& Fredrickson, 1996), we assess how CEOs with different career profiles are more (or less) likely to bid-up their price and receive higher initial pay when hired by firms facing different conditions. Given that CEOs with broad general career experience are - ceteris paribus - considered as more valuable in contexts of high informational requirements (Datta et al., 2002), we suggest that the disadvantageous effects toward extensive levels of generalist experience will become less pronounced in such contexts. Our contingency approach therefore allows us to observe how the relative economic value realized by CEOs with different career backgrounds at the time of appointment varies across different conditions.

\section{CEO Career Experience and Initial Compensation: A Generalism View}

Research subscribing to the generalism view of human capital suggests that the accumulation of broad-general career experience triggers higher CEO value and initial pay, for the following reasons. First, experience from various firms and industries enables CEOs to enhance their information processing abilities (DeFillippi \& Arthur, 1994). According to Dragoni et al. (2011), the accumulation of broad-general managerial skills pertains to holistic diagnoses of business problems. Indeed, Hitt and Tyler (1991) provided evidence that executives with broad-general career experience are inclined to use more criteria to assess strategic situations, and thereby make novel strategic decisions. Their higher information processing ability, as well as their diverse networks and information from a variety of domains (Kleinbaum, 2012), help generalist CEOs to effectively respond to the various informational demands facing large and complex organizations (Karaevli \& Hall, 2006). Such anticipated benefits increase a CEO's market value (Custodio et al., 2013), and ultimately result in higher initial compensation.

Second, the accumulation of broad-general career experience from different firm- and industry-settings increases a CEO's bargaining power in the labor market, as it widens the pool 
of employers in which the CEO's skills are considered as transferable and valuable (Frydman \& Saks, 2010; Frydman, 2019). Compared to executives with highly specialized experience from a single firm and industry environment, generalists possess knowledge and skills that are relevant for a wider pool of organizations at the time of selection (Frydman \& Jenter, 2010). This makes them attractive to a wider range of potential employers (Frydman \& Saks, 2010), which in turn increases their bargaining power in the labor market, as well as their ability to bid-up their price at the time of appointment (Chen, 2015; Falato et al., 2015).

Third, research has shown that career generalism and varied experience allows CEOs to strategically conceptualize across rapidly changing situational contexts (Dane, 2010). The acquisition of experience from different firms and industries helps managers to become fast and adaptive learners who can utilize diverse know-how across a variety of conditions (Karaevli \& Hall, 2006: 359). In Norburn's (1989) study, for example, “the CEOs' exposures to a wider variety of situations were seen as particularly critical [...] for complex multi-dimensional decision making" (Karaevli \& Hall, 2006: 364). The cognitive flexibility and knowledgetransfer ability ensure that generalist CEOs' human capital is perceived as valuable at the time of recruitment (Falato et al., 2015), and thereby prompts higher initial pay.

\section{CEO Career Experience and Initial Compensation: A Specialization View}

Whereas the generalist view highlights the labor market and economic advantages of acquiring broad-general career experience, another stream of research underscores the benefits of career specialization for CEOs. First, in contrast with generalists, specialist CEOs possess in-depth and expert-based knowledge (Datta et al., 2002). Such specialized experience is "localized, embedded, and invested within particular knowledge domains" (Kang \& Snell, 2009: 68). This enables specialist CEOs to develop a deep understanding of their areas of expertise, and to demonstrate career-focus to potential employer firms (Collins, 2001). Conversely, generalist CEOs often "suffer from the 'jack of all trades but master of none' 
syndrome" (Buyl, Boone, Hendriks, \& Matthyssens, 2011: 170), as their extensive career mobility often produces insufficient career focus and a relative lack of expertise. Also, experience from many areas and environments can trigger a cognitive information overload, preventing the development of specialized knowledge and experience depth (Dane, 2010). From this point of view, specialist CEOs may be considered as more valuable at the time of selection (Smith \& White, 1987) - and may thereby be offered a more generous initial compensation package that reflects their expertise-based credentials (Baruch \& Vardi, 2016; Mishra, 2014; Simmons \& Berri, 2009).

Second, scholars have stressed that individuals who gain specialized career experience signal human capital identity to potential employers (Salas, Rosen, \& DiazGranados, 2010). According to the stayer-mover model (Judge \& Watanabe, 1995), individuals who have shown more commitment to their current or previous employer companies (i.e., stayers) signify that they are likely to be committed to the hiring firm after their appointment - compared to frequent movers. This increases the labor-market value of individuals with specialized backgrounds, as it signals low risk-of-hiring at the time of recruitment (Munasinghe \& Sigman, 2004). Such signals may enhance a CEO's value (Astebro \& Thompson, 2011), resulting in higher initial compensation.

Third, studies have shown that specialization and expertise enable executives to effectively deal with decision making complexity (Simmons \& Berri, 2009). Through repeated observation, specialization facilitates the acquisition and recombination of experience (Smith \& White, 1987). Specialist CEOs possess greater "causal depth of knowledge" (Nelson \& Winter, 1982: 76) which "allows them to see through complexity" recognize what is essential, and ignore the rest at the time of strategic decision-making (Collins, 2001: 91). From a specialization view, high levels of career focus therefore equip CEOs with knowledge depth and enables them to increase their market value and initial pay. 


\section{CEO Generalism and Specialization: An Integrative View}

As described above, there are two opposing theoretical streams in the extant literature: (a) the one that adopts a generalism view to highlight the career-related and economic advantages of acquiring breadth of career experience, and (b) another that takes a specialization-view to underscore the disadvantages that occur from high levels of 'job hopping' and career mobility. While these streams are typically considered contradictory, we argue that their positions are not mutually exclusive. Our theoretical framework implies that the notions of generalism and specialization jointly represent the following trade-off: a gain in generalism and experience-breadth can only occur at the expense of sacrificing a respective degree of career specialization (Ferguson \& Hasan, 2013). By engaging in career mobility, individuals therefore invest in acquiring breadth of experience from different institutional settings while at the same time sacrificing a relative degree of career focus and specialization (Kim, 1989).

Following this premise, we postulate that the relationship between CEO generalist experience and initial compensation is neither positive-linear (as the generalism view suggests) nor negative-linear (as the specialization view suggests) - but rather inverted-curvilinear. Initially, as individuals move from low to moderate levels on the CEO generalist experience continuum, they acquire experience from different firms and industries, enrich their knowledge repertoires by building a required level of varied skills, and thus, gradually improve their market-value and initial compensation (Custodio et al., 2013). However, after reaching a threshold level of career mobility, the costs of sacrificing specialization start to outweigh the benefits of accumulating additional generalism - gradually resulting in a relative lack of knowledge-depth and expertise. The lower ability to signal expertise to potential employers at high levels of career generalism will give more gravitation to the arguments of the specialization-view - gradually promoting reduced CEO value and lower initial pay.

Thus, we suggest that an optimum at moderate levels of the CEO generalist-experience continuum exists. At this optimum, CEOs have accumulated breadth of experience from 
different contexts up to a level that allows them to retain and signal career specialization. The relative balance of breadth (generalism) and depth (specialization) dimensions equip CEOs with the required variety of skills (Dragoni et al., 2011), while at the same time enabling them to also demonstrate career focus and expertise to potential employers. The optimal balance of breadth and depth in a CEO's career profile will thus result in higher CEO market value and initial compensation.

Hypothesis 1: There is an inverted U-shape relationship between new CEO generalist experience and initial compensation.

\section{Organizational and Environmental Contingencies}

CEOs differ from each other with regard to their job demands (Hambrick et al., 2005)and these demands impact their initial compensation (Chen, 2005; Henderson \& Fredrickson, 1996). In their conceptual study, Hambrick et al. (2005) argued that there are two distinct forms of context-induced executive job demands - complexity challenges and performance challenges. While complexity challenges emanate from the multiplicity of the strategic and environmental context of the firm (Henderson \& Fredrickson, 1996), performance challenges occur under conditions of low prior firm performance (Chen, 2015). Following this premise, our contingency framework implies that the hypothesized inverted U-shape relationship may vary with the following three factors, nested at the firm and industry levels: (a) the firm's degree of diversification, (b) the prior performance of the firm (i.e., whether the firm has experienced a prior performance decline), and (c) the industry-level complexity. While industry complexity and firm diversification allow us to capture the complexity challenges facing the firm in its internal and external context (Henderson \& Fredrickson, 1996), the consideration of prior performance decline enables us to observe what Hambrick et al., (2005) defined as the performance challenges facing new CEOs - which may impact their initial compensation (Chen, 2015). 
Our contingency approach acknowledges that variation in CEO selection preferences exist not only between firms facing different conditions, but also among firms operating in similar contexts (Fulmer, 2009). Indeed, such variations in CEO selection preferences is an additional reason why the notions of generalism versus specialization should be considered as a continuum - rather than as two separate constructs. For example, while highly diversified firms are - ceteris paribus - inclined to emphasize generalist human capital in CEO selection due to their diverse strategic demands (Datta et al., 2002), some of these firms may seek to hire CEOs who possess more specialized experience from within the diverse context of the firm. However, as differences in terms of the value of generalist versus specialist experience are expected to be larger between firms in different contexts, than between firms within similar contexts (Carpenter, Sanders, \& Gregersen, 2001; Datta et al., 2002; Merluzzi \& Phillips, 2016), we expect that the relative pay of CEOs at different levels of the generalist experience continuum will vary across different conditions. By taking a contingency view (Carpenter et al., 2001; Henderson \& Fredrickson, 1996), our approach allows us to observe the relative rewarded-value of new CEOs with different human capital when hired by firms facing different conditions (Carpenter et al., 2001; Chen, 2015; Geletkanycz et al., 2001).

Firm Diversification. Firm diversification profoundly determines the informational demands facing CEOs in their jobs (Hambrick et al., 2005), and is therefore likely to influence CEO initial compensation (Harris \& Helfat, 1997; Henderson \& Fredrickson, 1996). In this study, we postulate that under conditions of high firm diversification, the downward slope of the inverted U-shape relationship will flatten (i.e., will become less steep) for the following reasons.

First, CEO generalist experience has often been described as a remedy to the various informational demands facing diversified organizations (Smith \& White, 1987). Informational requirements rise when intra-firm interdependencies "become more complex, [and] coordination and mutual problem solving demands increase" (Tushman \& Nadler, 1978: 616). 
As generalist managers possess diverse knowledge from various firm and industry environments, their career experience will be perceived as a relatively more valuable resource to deal with the diverse informational requirements facing large diversified corporations (Datta et al., 2002; Smith \& White, 1987). This will provide generalist CEOs with a greater opportunity to bid-up the price of their varied human capital at the time of selection (Carpenter et al., 2001). Under these conditions, the declining initial compensation returns at high levels of the CEO generalism continuum are therefore expected to attenuate.

Second, in highly diversified firms, CEOs need to implement coordination processes in the executive group that facilitate the establishment of effective synergies accross diverse business domains (Henderson \& Fredrickson, 1996). Studies have shown that generalist CEOs act as effective integrators of the executive group (Buyl et al., 2011; Georgakakis, Greve, \& Ruigrok, 2017), and possess the required variety skills to develop effective synergies among the various units of diversified organizations (Lawrence \& Lorsch, 1967). As generalist managers can act as effective integrators (Karaevli \& Hall, 2006), large diversified firms are expected to assign a relatively higher importance to their diversified career backgrounds at the time of selection - and compensate them with higher initial pay. Thus, we expect that the downward slope at high levels of the generalist experience continuum will become less pronounced (i.e., will flatten) under conditions of high firm diversification.

Hypothesis 2: Under conditions of high firm diversification, the downward slope of the inverted $U$-shape relationship between new CEO generalist experience and initial compensation will flatten (i.e., will become less pronounced).

Prior performance decline. According to Hambrick et al. (2005), executive job demands are not only determined by the complexity challenges that characterize the firm's internal and external environment, but also by the performance challenges surrounding the organization. At the time of CEO selection, firms that have experienced a major performance decline in preceding years face greater difficulties in attracting and recruiting executive talent (Child, 
1974). Compared to well-performing organizations, poorly performing firms are therefore more likely to pay an extra premium for attracting and appointing CEOs with valuable human capital (Chen, 2015). Along these lines, we argue that under conditions of declining prior firm performance, the downward slope of the inverted U-shape relationship will become less pronounced.

First, given the tendency to associate CEO generalist experience with the transfer of new and diverse knowledge, poorly performing firms are expected to consider generalist human capital as a remedy to their demands for renewal and change (Karaevli \& Hall, 2006). Indeed, recent research shows that in situations where innovation and change are essential, such as under conditions of declining prior firm performance, the possession of varied experience allows managers to effectively respond to organizational demands (Crossland, Jinyong, Hiller, \& Hambrick, 2014). By drawing on their diverse knowledge and human capital, generalist CEOs can innovate (Custodio et al., 2019), shake things up, and effectively alter the firm's performance status quo. Such anticipated benefits regarding the value of generalism under conditions that require innovation and change (i.e. declining prior performance) (Chen, 2015; Frydman, 2019) will reduce the lower-initial-pay effects at high levels of the generalist experience continuum.

Second, under conditions of high job demands due to declining prior firm performance, a CEO with experience from a variety of contexts will have a greater negotiating power compared to an extensive specialist CEO with more contextually-limited knowledge (often from within the poorly performing firm) (Custodio et al., 2013). Since generalist CEOs have more context-transferable skills and employment options (Frydman, 2019), they are expected to be in a relatively stronger position to negotiate a higher pay premium at the time of selection in order to take the leadership of a poorly-performing organization (Chen, 2015). Thus, given the overall tendency to associate generalist experience with innovation and change (Crossland et al., 2014; Custodio et al., 2019), as well as the greater ability of generalist CEOs to bid-up 
their price in contexts of prior firm performance decline (Chen, 2015), we expect that the downward slope of the inverted U-shape relationship will become less pronounced (i.e., will flatten) under such conditions.

Hypothesis 3: Under conditions of high prior firm performance decline, the downward slope of the inverted U-shape relationship between new CEO generalist experience and initial compensation will flatten (i.e., will become less pronounced).

Industry Complexity. Scholars have argued that the industry environment of the firm reflects executive job demands (Hambrick et al., 2005), and influences CEO initial compensation (Chen, 2015; Datta et al., 2002). A key industry-level factor related to CEO job demands is whether the firm operates in a more complex industry context where the market share is equally spread among a large number of competitors - vis-à-vis an oligopolistic (highly concentrated) industry context (Palmer \& Wiseman, 1999). Indeed, studies have shown that firms operating under conditions of high industry complexity (low industry concentration) experience higher demands for information processing and strategic renewal - as they strive to continuously respond to the moves and actions of various emerging competitors (Hambrick et al., 2005). To effectively respond to such industry-level competitive demands, firms in complex industries are likely to exhibit a stronger preference for recruiting and selecting generalist CEOs, who can promote strategic novelty by drawing on their broad-general career experience (Datta et al., 2002).

Accordingly, we argue that under conditions of high industry complexity, the downward slope of the inverted U-shape relationship will become less pronounced, for the following reasons. First, highly complex (non-concentrated) industries are characterized by lower barriers to entry (Dess \& Beard, 1984). Organizations that operate in such industries require CEOs who can develop flexible strategies that enable the firm "to fend off attacks and retaliations from varied competitors" (Nadkarni, Chen, \& Chen, 2016: 1143). Given that career generalism relates to the establishment of flexible strategic mindsets (Dane, 2010) and to a higher 
information processing ability (Dragoni et al., 2011), CEO with high levels of generalist experience will be seen as a remedy to the diverse competitive demands of the industry. This provides CEOs at high levels of generalism with greater opportunities to negotiate a higher price for their diverse experience at the time of recruitment. Under such conditions, the negative effects of high levels of CEO generalism on initial compensation will therefore be attenuated resulting in a less steep downward slope of the inverted U-shape relationship.

Second, industry complexity reflects a firm's need to frequently promote strategic renewal (Palmer \& Wiseman, 1999). On the one hand, firms in non-complex, oligopolistic industries are characterized by higher levels of competitive interdependence. Hence, they need specialist CEOs who can develop strategies that match with the industry's pre-established norms and standards (Tang, Li, \& Yang, 2015). Conversely, organizations in highly complex industries require executives who can frequently alter the firm's strategic status quo - and realign the organization with the frequently shifting competitive demands of the external context (Palmer \& Wiseman, 1999). As generalist CEOs with diverse experience exhibit a tendency toward experimentation and change (Crossland et al., 2014), and as industry complexity poses higher demands for strategic adaptation (Palmer \& Wiseman, 1999), we expect that high levels of career generalism will be perceived as a relatively more valuable resource in complex industry contexts. While some firms in concentrated (less complex) industries may decide to hire generalist CEOs with the aim to spur innovation (Custodio et al., 2019), the general need of firms in complex industries to deal with diverse informational requirements will drive them to place greater emphasis on diverse career experience at the time of CEO selection. This provides generalist CEOs with better opportunities to bid-up the price of their diverse human capital - and thus to realize higher initial pay.

Hypothesis 4: Under conditions of high industry complexity, the downward slope of the inverted $U$-shape relationship between new CEO generalist experience and initial compensation will flatten (i.e., will become less pronounced). 


\section{METHODS}

\section{Sample and data}

Our data comprises CEO appointments at a sample of large stock-listed firms based in four countries (i.e. Germany, the Netherlands, Switzerland, and the UK) over a seven years between 2007 and 2013. Firms listed in the stock exchanges of the selected countries comply with International Financial Reporting Standards (IFRS) (Armstrong, Barth, Jagolinzer \& Riedl, 2010; Deloitte, 2007) and are therefore required to disclose information with regard to the realized and estimated (ex-ante long term) pay received by CEOs. In addition, publicly listed firms in these countries select CEOs with heterogenous career backgrounds and experiences - providing an appropriate setting for investigating the link between CEO career generalism and initial compensation.

Our sample firms were selected by first ranking all stock-listed firms by market capitalization in each of the four target countries and subsequently identifying the 100 largest firms in each country. Next, we excluded firms that fell within the European Commission's (2016) definition of small and medium-sized enterprises; were financial investment units with a primary industry categorization of 67 (i.e., investment holdings/offices/trusts); became part of a new corporate entity following a merger/acquisition or were nationalized during the observation period; were non-autonomous subsidiaries of a parent firm; and were familycontrolled (Miller, Minichilli, \& Corbetta, 2013). These criteria were applied to ensure that our sample firms were a heterogeneous yet consistent and comparable set of large publicly held organizations.

Following the application of these criteria, our selected sample was 330 large stock-listed European firms. We then identified all CEO appointments between January 1, 2007 and December 31, 2013 in these 330 companies. The total number of new CEOs identified over the seven-year period was 305. To ensure comparability among CEOs, we excluded interim appointments or cases where the new CEO had shared leadership responsibilities with another 
co-CEO. Information about executives and directors was obtained through manual data collection from annual reports, company websites and databases that provide information about executive career profiles (e.g., Nexis and Who is Who). Firm- and industry-level data was retrieved from Bloomberg and ThomsonONE. The exclusion of missing observations led to a final sample of 197 CEO appointments. We ran Kolmogorov-Smirnov tests to observe whether the missing observations systematically differ from the final sample. These tests show that the distributions of the variables CEO total initial compensation, return on assets (ROA), and CEO career length do not significantly differ between the two samples.

\section{Dependent variable}

CEO total initial compensation is measured as the total sum of all forms of remuneration the firm provided to the new CEO in the first complete fiscal year of appointment (Bragaw \& Misangyi, 2017; Falato et al., 2015). Data on CEO compensation (in Euros) was retrieved from the Bloomberg Professional database. Per Bloomberg professional, our variable CEO total initial compensation includes total fixed salary, bonus, stock options, restricted stock, all other long-term incentives, and other miscellaneous pay (e.g., life insurance, pension benefits, tax reimbursements) as reported by the companies. To enhance completeness and accuracy, data were cross-checked and supplemented from firms' annual reports. To deal with heteroskedasticity and account for the fact that long term pay valuation approaches are likely to over- or under-value CEO long term pay (Conyon \& Murphy, 2000), we transformed this variable to its natural logarithm (Chen, 2015; Falato et al., 2015).

We focus on new CEO initial compensation as this provides a context which is relatively less influenced by the managerial power issues that occur as CEOs accumulate tenure in the firm. Over time, CEOs accumulate power in the organization and can thereby exert an increasing influence on the level and structure of executive remuneration (for a meta-analysis, see: van Essen et al., 2015). Such accumulation of power over the CEO's tenure may mask the 
effects of CEO human capital on pay (Chen, 2015; Graffin et al., 2020). According to Chen (2015: 1895; 1896), focusing on CEO initial compensation allows scholars to unveil "the difficulty of teasing out the effect of organizational entrenchment. [CEO] initial compensation negotiation is relatively immune from the entrenchment of CEO power." Focusing on CEO total initial compensation therefore allows us to adequately examine the hypothesized relationships in a context where CEO pay is mostly determined by human capital considerations, rather than by managerial power (Chen, 2015; Graffin et al., 2020).

Based on Bloomberg Professional, our study captures the estimated value of restricted stock grants at the grant date (i.e., in the first full year of the CEO's appointment) as reported by the companies. This is the approach to valuing restricted stock grants required by the IFRS in the IFRS-2 share-based reporting principles with which stock-listed firms in the selected countries comply (Armstrong et al., 2010; Deloitte, 2007). Further, the ex-ante value of stock option grants is captured by most firms using the Black-Scholes option pricing model - which is a principal approach suggested by the IFRS for stock options with an expiration date (i.e., European options) (Conyon, Peck, \& Sadler, 2001). It is important to note that considering the ex-ante value of stock options and resrticted stock offered to the new CEO in the first complete fiscal year of appointment as reported by the companies - rather than the ex-post value of these grants - fits our theoretical approach. This is because the firm will value the CEO's human capital and offer respective initial pay by considering the ex-ante (rather than the unknown expost) value of equity-based pay at the time of the offer (Chen, 2015).

\section{Independent variable}

To measure the level of CEO generalism versus specialization we used Blau's (1977) formula: $1-\sum p_{i}{ }^{2}$, where $p$ is the proportion of a CEO's career (in years) spent in a firm or industry $i$ (Ferguson \& Hasan, 2013). According to Ferguson and Hasan (2013), Blau's index is suitable for measuring the level of generalism versus specialization in an individual's career 
background, as it captures both the breadth of knowledge an individual has acquired from different firms and industries as well as the relative proportion of career time spent in each firm and industry. To obtain the overall $C E O$ generalist experience, we first calculated the Blau index for each component separately (i.e., firm and industry experience), and then summed the two components to create a composite variable. High scores indicate high career generalism, while low scores indicate high career specialization (Ferguson \& Hasan, 2013). To test whether the two components (i.e., firm and industry experience) load on the same factor, we conducted factor analysis in Stata 15.1. Results show that the two components load onto the same factor with an alpha coefficient of 0.87 and an eigenvalue of 1.37 - indicating that aggregation of the two components is appropriate.

To ensure accuracy in the coding of CEOs' career experience, we adopted the following procedure. First, we searched annual reports and corporate websites to identify information about the CEOs' career histories (beginning at the start of the CEO's career and ending at the year of appointment as CEO in the focal organization). If complete information was not available, we searched other secondary sources that provide CEO biographical and career information (e.g., Nexis and Who is who). In our analysis, we used only observations with complete information on CEO career history.

\section{Moderator and control variables}

Firm diversification was calculated using the entropy measure of diversification in the year of the CEO's appointment, expressed as $\sum_{i=1}^{N} P_{i} \ln \left(\frac{1}{P_{i}}\right)$, where $P$ is the share of the firm's sales in an $i$ industry segment (Geletkanycz, Boyd, \& Finkelstein, 2001). Higher scores indicate higher firm diversification. Further, to measure prior firm performance decline we took the firm's ROA two years before the new CEO's appointment ( $t-2)$ and subtracted the firm's ROA one year before the new CEO's appointment year (t-1) (Tuggle, Sirmon, \& Reutzel, 2010). Higher scores indicate a greater decline in ROA prior to succession. Following Dess and Beard 
(1984), industry complexity was measured using the Gibbs-Martin (1962) industry concentration ratio, calculated as $1-\left[\sum x^{2} /\left(\sum x\right)^{2}\right]$, where $x$ is the total market share of all companies from the same industry within the sample. Higher scores indicate higher industry complexity.

We employed several control variables to account for potential confounding factors. First, MBA degrees are widely considered as general business education programs and have thus been linked to generalist human capital and initial executive pay (Datta \& Iskandar-Datta, 2014). We thus controlled for $C E O M B A$, measured as a dichotomous variable taking the value of 1 for CEOs with an MBA degree and 0 otherwise. To account for the overall stock of a CEO's career experience, we controlled for CEO career length (in years) from the CEO's career start to the year of appointment as CEO in the focal organization. Further, individuals who have been CEOs of other firms prior to their appointment at the focal organization are likely to receive higher initial pay (Bragaw \& Misangyi, 2017; Custodio et al., 2013). Thus, we controlled for prior CEO experience. This variable takes the value of 1 if the individual held the role of CEO at another stock-listed firm prior to appointment in the focal organization, and 0 otherwise.

Further, we controlled for CEO functional experience variety. This variable was calculated using Blau's (1977) formula, expressed as $1-\sum p_{i}{ }^{2}$, where $p$ is the relative proportion of a CEO's career time spent in functional category $i$. Similar to prior research, we coded a CEO's functional experience using the following ten categories: manufacturing\&engineering, production, accounting\&finance, R\&D, marketing\&sales, general managemen\&administration, legal affairs, human resources, policy/strategy/corporate development, and other (Michel \& Hambrick, 1992). In addition, studies have shown that prior managerial experience often relate to higher CEO initial compensation (Bragaw \& Misangyi, 2017). This is based on the notion that experience from general management posts is associated with skilled leadership, which is an important experience-related attribute that may lead to 
higher CEO initial compensation (Fulmer, 2009). To account for this, we controlled for the proportion of career time the CEO had spent in general management posts - defined as positions with administration and general management responsibilities. To calculate the career in general management, we divided the total number of years the CEO had spent in general management/administration functional roles by overall CEO career length.

Moreover, CEOs who have worked for a string of highly reputable companies would exhibit stronger legitimacy in the executive labor market and would therefore naturally command higher initial compensation (Bidwell, Won, Barbulascu, \& Mollick, 2015). Following prior studies (Boivie, Graffin, \& Gentry, 2016), we thus controlled for the number of companies in which a CEO had worked over his or her career that were included in the Fortune World's Most Admired companies. The Fortune World's Most Admired Companies index evaluates company reputation based on nine different criteria: innovation, people management, use of corporate assets, social responsibility, quality management, financial soundness, long-term investment value, quality of products/services and global competitiveness - and ranks the top companies in each industry worldwide together with contenders (Boivie et al., 2016). Similar approaches for evaluating CEOs' career legitimacy have been applied by scholars in the field of CEO human capital and compensation (Bidwell et al., 2015). Controlling for this aspect allows us to consider potential confounding effects that may derive from CEO legitimacy in prior career experience.

Following Falato et al. (2015), we also controlled for CEO fast-track career to account for CEOs with exceptional career progression. According to Falato et al. (2015: 2850), a fast track career is a proxy for 'the quality of the CEOs' career track records based on how fast they cleared the bar for their first CEO jobs. The intuition for why this variable is a signal of skills is based on the competitive sorting theories of firm hierarchy where [...] more talented executives will spend less time on the corporate ladder and sooner clear the CEO hurdle". In their study, Falato et al. (2015) underscore that the notion of a CEO fast track career may be 
biased by the fact that CEOs who started their career earlier in time are likely to have been less mobile compared to those who started their career more recently. To overcome this issue, they clustered CEOs based on their age into three cohorts (centiles) and compared them with the median 'time to CEO' within their respective cohort. Consistent with Falato et al. (2015), we measured time to CEO by first defining three centiles of new CEO career length within our sample, and then subtracting the time (in years) an individual took to become CEO for the first time in his or her career from the median time to CEO within his or her respective career length cohort. This allowed us to evaluate the impact of CEO fast-track careers by comparing CEOs who started their career at around the same point in time.

We controlled for outside CEO origin, coded as 1 if the new CEO had two or less years of firm tenure in the year of appointment, and 0 if the CEO had firm tenure of more than two years (Hambrick \& Fukutomi, 1991). To account for whether the CEO had acquired experience from within the firm's focal industry, we controlled for CEO industry specific experience. This variable was coded as 1 for CEOs who had one or more years of prior working experience in the focal firm's industry, and 0 otherwise (Chung \& Luo, 2013). To capture any gender-related impact on CEO initial compensation, we controlled for CEO gender - a dummy variable taking the value of 1 for female CEOs and 0 otherwise.

As initial pay might be influenced by the attributes of the prior CEO, we controlled for prior CEO tenure, reason for departure (i.e., retirement), and predecessor succession origin. First, predecessor tenure was calculated as the number of years the predecessor served as CEO in the focal firm. Previous research has suggested that long-tenured CEOs have greater power in the firm (Hambrick \& Fukutomi, 1991). Thus, a long-tenured departing predecessor might influence the new CEO's initial compensation. Second, scholars have shown that predecessor CEOs who leave the firm due to ordinary retirement are likely to have a key influence on the succession process (Shen \& Cannella, 2002), and on the new CEO's initial compensation (Lorsch \& Maciver, 1989). Similar to prior studies, predecessor retirement was coded as 1 if 
the predecessor CEO was older than 65 in the year of the new CEO's appointment and 0 otherwise (Shen \& Cannella, 2002). Third, we controlled for predecessor hiring mode - given that predecessors who were hired from outside the firm are likely to have a higher starting pay compared to those appointed from the organization's internal ranks (Harris \& Helfat, 1997). This variable was coded as 1 if the predecessor CEO was hired from outside the firm (i.e. had a firm tenure of two or less years when they were hired as CEOs in the focal firm (Hambrick \& Fukutomi, 1991; Zhang \& Rajagopalan, 2004)) and 0 otherwise.

To account for the degree of firm-specific experience of other top management team (TMT) members, we controlled for average TMT firm tenure, calculated as the average number of years top managers (excluding the CEO) had worked in the focal organization at the time of the new CEO's appointment. Further, we controlled for $C E O$ duality, measured as a dichotomous variable taking the value of 1 if the new CEO was also appointed as board chair and 0 otherwise (Chen, 2015). Corporate governance scholars have argued that vigilant boards influence executive pay (Zorn, Shropshire, Martin, Combs, \& Ketchen, 2017). Thus, we controlled for board independence, measured as the proportion of outside (non-employee) directors.

Research shows that firm size reflects the job demands facing executives, and thus may act as a determinant of CEO compensation (Peng, Sun, \& Markoczy, 2015). Hence, we control for firm size, measured as the natural logarithm of annual sales. To account for a company's international presence, we also controlled for the firm's degree of internationalization (DOI) measured as the ratio of foreign sales to total sales (Tallman \& Li, 1996). Industry munificence was calculated as the regression coefficient of time measured in years on the annual sales average in a firm's primary industry, divided by the overall mean sales of the whole study period. Industry dynamism was measured as the dispersion of the regression line obtained in the estimation of munificence (Dess \& Beard, 1984). Finally, we controlled for country-level CEO discretion to account for cross-country differences in CEO managerial discretion, 
measured using Crossland and Hambrick's (2011) discretion scores for each of the four countries. To account for macro-economic fluctuation effects, we included year dummies in all models.

\section{Analytical Strategy}

Our study is based on data nested at three levels: CEOs within firms in years (Level 1), firms within industries (Level 2), and variations across industries (Level 3). We therefore employed a three-level hierarchical linear modeling (HLM) analytical approach with robust standard errors (Rabe-Hesketh \& Skrondal, 2008; Raudenbush \& Bryk, 2002; Sauerwald, van Oosterhoot, van Essen, \& Peng, 2018). To facilitate interpretation of results, all variables excluding dichotomous and those with a meaningful zero were centered at the grand mean (Dawson, 2014; Rabe-Hesketh \& Skrondal, 2008).

The use of an HLM technique allows us to account for systematic variation among observations (Raudenbush \& Bryk, 2002), given that, for example, firms in the same industry are more likely to have common hiring patterns and CEO selection preferences compared to firms in different industries (Datta et al., 2002). In addition, the use of an HLM technique enables us to observe the total variance in CEO initial pay explained by individual-, organizational- and industry-level factors, and thereby allows to adequately capture the multilevel nature of CEO initial compensation (Graffin et al., 2020; van Essen et al, 2012).

As CEO initial pay may be affected by CEO turnover and selection factors, we applied a Heckman two-stage approach to deal with potential endogenous bias and sample selection (Heckman, 1979). In the first step, the Heckman approach relies on a Probit model to predict the likelihood of CEO turnover in the original target population of companies (i.e., including those companies that did not change their CEOs during the study period). Consistent with prior research, we employed the frequency (i.e., percentage) of CEO turnover in each firm's firstdigit SIC industry as an instrument. To ensure that our instrumental variable was independently 
determined, we excluded the focal company from the industry-average CEO turnover measure (Zorn et al., 2017). Based on the Heckman's Probit model (Table I in Online Supplement), we calculated the inverse Mills ratio and used it as a control variable in our main analysis. This way, our analysis accounts for potential unobserved factors associated with CEO replacement that may concurrently impact new CEO selection and initial compensation (Falato et al., 2015).

\section{RESULTS}

To test whether a multilevel analytical approach is appropriate based on the structure of our data, we first run the null HLM model - where only the dependent and predictor variables are included. The overall null HLM model is significant ( $p$-value $=.000)$, implying that a three level HLM technique is appropriate (Rabe-Hesketh \& Skrondal, 2008). Further, we examined the decomposition of variance in the null HLM model. Results show that the largest proportion of variance in CEO total initial compensation is explained at the firm-level (54 percent). With another large proportion explained at the individual level (35 percent). Finally, a remaining smaller proportion of variance is explained at the industry level. This demonstrates that CEO initial compensation is explained by factors nested at different layers of context - with the firmlevel and the individual-level playing the most central role (Table II in online supplement).

$* * * * * * * * * * * * * * * * * * * * * * * * * * * * * * * * * * * * * * * *$

INSERT TABLE 1 ABOUT HERE

$* * * * * * * * * * * * * * * * * * * * * * * * * * * * * * * * * * * * * * * *$

Table 1 presents means, standard deviations and correlations among variables, while Table 2 provides results of the main HLM analysis with robust standard errors (Rabe-Hesketh \& Skrondal, 2008). To check for multicollinearity, we performed variance inflation factor (VIF) tests after OLS regression (Cannella et al., 2008). With an average VIF of 1.73 in Model 1 of Table 2, these tests indicate that our results are unlikely to be affected by multicollinearity. Model 1 in Table 2 tests for a linear (i.e., non-quadratic) relationship, while Models 2 to 5 add 
the squared term and each interaction effect separately. Finally, Model 6 includes all main and interaction effects. As Model 1 in Table 2 shows, the linear relationship between CEO generalist experience and CEO total initial compensation is not significant $(b=0.04$; s.e. $=0.11$; $p$-value =.739). Hypothesis 1 predicts an inverted U-shape relationship between CEO generalist experience and CEO total initial compensation. Results support this hypothesis $(b=-0.48$; s.e. $=0.21 ; p$-value $=.020$ in Model 2 and $b=-0.97 ;$ s.e. $=0.38 ; p$-value $=.011$ in Model 6 of Table 2). As further shown in Figure 1, the acquisition of broad-general career experience increases CEO initial pay up to a threshold after which CEO value and initial compensation gradually declines.

To practically interpret this finding, we estimated the effect size at one standard deviation above and below the mean of our predictor variable (Dawson, 2014). Results show that CEO generalism at one standard deviation above the mean amounts to a reduction in CEO total initial compensation of $10.2 \%$; while at one standard deviation below the mean CEO total initial compensation is reduced by $30.1 \%$. Following the recommendations of Lind and Mehlum, (2010) and Haans, Pieters, and He (2016) we performed curvilinearity tests after an OLS regression with robust standard errors and all variables uncentered to confirm the existence of the inverted U-shape relationship. First, we examined whether the lower and the upper slopes of the observed inverted curvilinear relationship were significant (Haans et al., 2016). Results show that both the lower bound $(p$-value $=.009)$ and the upper bound $(p$-value $=.004)$ of the observed relationship are significant - confirming the presence of an inverted U-shape curve.

To ensure the existence of an inverted U-shape relationship, we conducted the following tests (see Table III of the online supplement). First, we performed the Sasabuchi (1980) curvilinearity test - as recommended by Lind and Mehlum (2010). This test also supports the overall presence of an inverted curvilinear relationship ( $p$-value $=.009)$. Further, using Fieller's standard errors, we checked whether the curve's estimated turning point (i.e., extreme point) is within the range of our independent variable and its Fieller intervals (Haans et al., 2016). In our 
case, the curve's estimated turning point in the OLS regression analysis (0.71) is both within the range of CEO career generalism ( 0 to 1.63$)$ and its Fieller intervals $(0.39 ; 0.94)$. This indicates that the observed curvilinear effect is appropriately captured. Finally, to check whether there is a cubic (S-shaped) rather than a quadratic relationship, we ran our HLM analysis by adding a cubic term of CEO generalist experience in Model 2. Results do not provide support for a cubic relationship $(b=-0.36$; s.e. $=0.51 ; p$-value $=.475)$.

Hypothesis 2 posits that the downward slope of the inverted U-shape relationship between CEO generalist experience and initial compensation will flatten (become less pronounced) under conditions of high firm diversification. Results do not provide support for this hypothesis. Our findings show that the hypothesized effect is non-supported $(b=0.54$; s.e. $=0.34$; $p$-value $=.114$ in Model 3, and $b=0.55 ;$ s.e. $=0.36 ; p$-value $=.124$ in Model 6).

Hypothesis 3 suggests that the downward slope of the inverted U-shape relationship becomes less pronounced under conditions of declining prior firm performance. In contrast to our initial expectations, results show that CEOs with relatively moderate levels of generalist experience receive even higher initial compensation compared to those at the extremes when they are appointed by firms with performance decline in preceding years (i.e., the inverted Ushape relationship becomes more pronounced under such conditions) $(b=-0.07 ;$ s.e. $=0.02 ; p$ value $=.001$ in Model 4 ; and $b=-0.06 ;$ s.e. $=0.02 ; p$-value $=.013$ in Model 6 ). While this finding seems counterintuitive and is in contrast to hypothesis 3, it has a logical appeal. It is in line with prior research on organizational adaptation (Haveman, 1992; Sastry, 1997), which suggests that, under conditions of declining firm performance, firms seek to both (a) strengthen established routines and specialized competencies, and (b) explore radically new competencies. Given that CEOs with moderate levels of generalism possess a relative balance of broad-general and narrow-specialized experience compared to extensive generalists or extensive specialists, they may be considered as better equipped to respond to the simultaneous exploration and exploitation needs facing firms with declining performance (Boh, Evaristo, \& Ouderkirk, 
2014). Thus, their blend of broad and specialized human capital is compensated higher at the time of selection under such conditions (see Figure 2).

Indeed, our effect size estimates show that under conditions of high prior firm performance decline, $\mathrm{CEO}$ generalist experience at one standard deviation above the mean triggers a reduction in CEO total initial compensation of $17.9 \%$, whereas one standard deviation below the mean shows a reduction in CEO total initial compensation of $39.3 \%$. Under conditions of low prior firm performance decline, CEO generalism at one standard deviation above the mean shows a reduction in CEO total initial compensation of only $2.9 \%$, and at one standard deviation below the mean the reduction in CEO total initial pay is $21.2 \%$.

Finally, Hypothesis 4 posits that under conditions of industry complexity, the downward slope of the inverted U-shape relationship flattens (i.e. becomes less pronounced). Our results substantiate this hypothesis $(b=3.38 ;$ s.e. $=1.34 ; p$-value $=.012$ in Model 5, and $b=3.19$; s.e. = 1.46; p-value =.029 in Model 6). As Figure 3 shows, under conditions of high industry complexity, the downward slope of the inverted U-shape relationship becomes less pronounced (i.e., flattens). The effect size estimates show that under conditions of high industry complexity, CEO generalism at one standard deviation above the mean triggers a slight increase in CEO initial compensation of $2.1 \%$. Under conditions of low industry complexity CEO generalism at one standard deviation above the mean results in a decrease in CEO initial pay of $21.0 \%$. Overall, these results show that under conditions of high industry complexity, there is no negative impact of high career generalism on CEO total initial pay - substantiating the hypothesis that the inverted U-shape relationship flattens under such conditions.

$* * * * * * * * * * * * * * * * * * * * * * * * * * * * * * * * * * * * * * * *$

INSERT TABLE 2 ABOUT HERE

$* * * * * * * * * * * * * * * * * * * * * * * * * * * * * * * * * * * * * * * *$ 


\section{Robustness Tests}

We also employed the Durbin and Wu-Hausman approaches to ensure that our results are not affected by endogeneity beyond sample selection. In accordance with prior studies, we employed the one-digit SIC industry average of CEO generalism as an instrument (excluding the focal firm) (Zorn et al., 2017). We conducted the Basmann test to check for the appropriateness of the instrument. This test confirmed the suitability of the selected instrument $\left(c h i^{2}=2.64 ; p=.104\right)$. Results of the Durbin $(p=0.853)$ and Wu-Hausman $(p=0.866)$ tests provided no evidence of endogeneity.

We also conducted the following supplementary analyses to check the sensitivity of our findings to alternative operationalizations of key variables. First, we performed additional analyses with CEO initial cash compensation (the sum of fixed salary and bonus), and CEO initial long term pay as dependent variables. We did this to observe whether both initial cash and initial non-cash compensation demonstrate an inverted U-shape pattern. Following prior research, initial long-term pay was transformed using the inverse hyperbolic sign function, instead of natural logarithm, given that some CEO contracts do not include a long term pay component (Kolev, Wiseman, \& Gomez-Mejia, 2017). The supplementary analyses show that with both components of CEO total initial pay our results follow similar patterns. The observed effects for CEO initial cash pay, however, are more robust than the observed effects for the long-term initial CEO pay component. This is in line with the arguments of prior research that "because experience is relatively permanent, stable, and cumulative, it is most likely to influence pay via the permanent, stable, and cumulative dimension of pay" (i.e., cash compensation) (Fulmer, 2009: 668). Results of these analyses are available on Table IV of the online supplement. 
Second, studies have shown that boards and compensation committees often set CEO pay by comparing the initial compensation offered to new CEOs in other industry peer firms (Seo, Gemache, Devers, \& Carpenter, 2015; Wowak, Hambrick, \& Henderson, 2011). To account for this, we followed the approach suggested by Shin (2016) and re-ran our analyses by adjusting CEO total initial compensation to the average CEO total initial pay at other sample firms in the same one-digit SIC industry as the focal organization. This allows us to consider whether new CEOs with different career backgrounds are paid more, or less, in their first full year of appointment compared to the mean of total initial CEO pay in the same industry - i.e. beyond the two-digit industry nesting we use in the HLM analysis. Results of these analyses do not substantially differ from those reported in Table 2 and are available in Table $\mathrm{V}$ of the online supplement. Third, our study uses a multi-country sample where country-level institutional factors may affect CEO total initial compensation (van Essen et al., 2012). While our main analysis accounts for this by controlling for cross-national differences in CEO discretion, we re-estimated our empirical models with CEO total initial compensation adjusted to the countryaverage of CEO initial pay. The results do not substantially differ from our main analysis (Table 2) and are available in Table VI of the online supplement.

\section{DISCUSSION}

This study examined the link between CEO generalist career experience and CEO initial compensation. We have conceptualized and empirically tested a contingency framework that reconciles two opposing theoretical streams, namely: (a) the generalism view which contends that managers and CEOs with broad-general career backgrounds are more valued by the market for executive labor and thus receive higher initial pay; and (b) the specialization view which underscores the importance of specialized human capital, and its career-related and economic advantages. By bringing together these seemingly opposing perspectives, our research considers both the benefits and costs of accumulating varied career experience - and suggests 
that the relationship between CEO career generalism and CEO initial compensation follows an inverted U-shape form. Our results support this prediction (Figure 1). They also reveal that the observed inverted U-shape relationship varies with the firm's internal and external context (Figures 2 and 3). Overall, our study shows that penalties in the economic value of executive human capital (i.e., initial compensation) at the time of CEO selection occur not only for executives who extensively specialize throughout their careers and thus lack generalist skills (Custodio et al., 2013; Frydman, 2019; Murphy \& Zabojnik, 2004), but also for those who extensively engage in career mobility across firm and industry contexts.

Our study contributes to the literature of strategic leadership and CEO initial compensation in multiple ways. First, it highlights and resolves a longstanding theoretical debate over whether CEOs with generalist versus specialist human capital receive higher initial pay. Our theory and results stress that the notions of generalism and specialization should be considered together, as CEOs with balanced careers (i.e., those who maintain a relative balance between generalism and specialization) are those who are most valued by the market for executive labor and thus receive higher initial compensation. Broadly speaking, our results have implications for the 'resource-based' perspective of CEO human capital (Campbell, Coff, \& Kryscynski, 2012; Carpenter et al., 2001; Finkelstein et al., 2009; Mackey, Molloy, \& Morris, 2014), as well as for the emerging literature on CEO initial pay (Bragaw \& Misangyi, 2017; Chen, 2015; Graffin et al., 2020). Prior studies have regarded broad-general managerial skills as a relatively scarce human capital resource (Mackey et al., 2014), arguing that CEOs with broad-general experience from various firms and industries are those who receive higher initial remuneration returns as a result of their prior career investments (Custodio et al., 2013). Yet, our results show that CEOs at moderate levels of career generalism are perceived as more valuable in the executive labor market (see Figure 1). Neither the frequent job-hoppers who have been highly mobile across firm and industry environments throughout their professional 
career, nor those executives who have spent their entire career in a single firm and industry are likely to extract the highest value at the time of their appointment.

Indeed, our study extends the arguments of Murphy and Zabojnik (2004: 193), Frydman (2019) and Custodio et al. (2013), who stress that generalist experience is "priced" while specialist experience is "unpriced" in the modern CEO labor market. We demonstrate that career investments in generalism and specialization are most 'priced' when they are proportional and balanced out over an individual's career development. Acknowledging the value of balancing generalism and specialization in executive careers is important from both a theoretical and a practical point of view - as it allows to appreciate not only how CEO initial pay reflects the prior career investments of individual executives (Devers et al., 2007; Falato et al., 2015), but also to probe the frequently invoked assumption that extensive career mobility is the 'path to prosperity' for newly appointed CEOs. If firms are to attract and develop executives with valuable human capital (Custodio et al., 2013; Geletkanycz et al. 2001), and as compensation consultants strive to provide accurate predictions about the economic value of CEOs' career credentials (Conyon, Hass, Peck, Sadler, \& Zhang, 2019), the notions of generalism and specialization should be considered in conjunction.

Second, our study contributes to our understanding of how the relationship between CEO career background and initial compensation varies with contingencies. In their conceptual study, Hambrick et al. (2005) distinguished between two different sources of 'context-induced' job demands facing CEOs - i.e., complexity challenges and performance challenges. They claimed that these two sources of job demands are likely to pose different challenges for CEOs and are thereby expected to have different effects on CEO-level outcomes (including initial compensation). In a recent study, Chen (2015) also argued that CEO initial pay is influenced by the job demands that newly hired CEOs are likely to face after taking charge. Contributing to this nascent area, our study shows that different types of context-induced executive job 
demands have differential effects on the relationship between CEO career background and initial compensation.

Specifically, in highly complex industries, the negative effects of extensive levels of CEO career generalism on initial compensation tend to become less pronounced - i.e. the downward slope of the inverted U-shape relationship flattens (see Figure 3). In contrast to our ex-ante expectations, however, our analysis does not provide significant support for a moderating effect of firm diversification - which has been regarded by prior studies as another source of firmlevel complexity influencing CEO pay (Henderson \& Fredrickson, 1996).

Moreover, building on the notion that poorly performing firms tend to value and compensate new CEOs with generalist experience more highly (Chen, 2015; Custodio et al., 2019), we hypothesized that the downward slope of the inverted U-shape relationship will flatten in situations of prior performance decline. In contrast to our initial expectations, our results show that, under such conditions, CEOs at moderate levels of the generalist experience continuum realize even higher initial pay relative to extensive generalists and extensive specialists (see Figure 3). The differences in our findings regarding the moderating effects of prior performance vis-à-vis industry complexity may be attributed to the different nature of executive job demands they pose to CEOs (Hambrick et al., 2005).

On the one hand, declining firm performance implies a need to hire CEOs who are likely to implement changes that will improve organizational performance (Chen, 2015). Research has shown that under conditions of declining prior performance, firms need to focus on strengthening their existing capabilities and advantages, as well as discovering new paths and competencies (Haveman, 1992; Sastry, 1997). In such conditions, a CEO with moderate levels of generalist experience may be perceived as particularly valuable in the firm's quest to both strengthen existing competencies and explore new ground (Chen, 2015; Lugeanu \& Zajac, 2019). In addition, following a period of declining performance, firms face greater difficulties in recruiting and appointing executives with valuable human capital (Philips \& Gully, 2015). 
Therefore, they may offer a relatively higher pay premium to attract and appoint CEOs with valuable skills and experience (Chen, 2015). As CEOs at moderate levels of the generalist experience continuum are generally more valued in the market for executive labor (see Figure 1), they are likely to request and receive higher initial pay to take on the leadership of poorly performing firms (see Figure 2). Conversely, industry complexity refers to the demands that derive from the complexity facing the firm in its environment (Hambrick et al., 2005). Under these conditions, the possession of highly diverse career experience is more likely to be valued by the firm, as it enhances the firm's information processing capacity and external connections - thereby triggering a relatively lower 'penalty' in initial compensation for CEOs with high levels of generalist experience (Figure 3).

Finally, another contribution of our study rests on the use of a multilevel theoretical and analytical approach in examining the determinants of CEO initial compensation. Scholars have recently recognized that the construct of CEO initial compensation is multilevel (Graffin et al., 2020) - as it comprises micro (individual), meso (organizational), and macro (industry) level drivers. At each of these levels, different mechanisms affect CEO initial compensation. Whereas scholars have separately investigated the individual (Harris \& Helfat, 1997), organizational (Chen, 2015), and industry (Finkelstein \& Boyd, 1998) determinants of CEO pay, the conjoint impact of multilevel factors has rarely been explored (for exemptions see: Graffin et al., 2020; van Essen et al., 2012). Contributing to this emerging area, our study underscores the complex and multilevel nature of the relationship between CEO career experience and initial compensation.

\section{Practical Implications, Limitations and Future Research}

Our study has important practical implications. Practitioner-oriented articles advocate that in today's increasingly uncertain environment, "breadth of perspective trumps depth of knowledge" (Mansharamani, 2012:1), and that extensive "breadth, not depth, will be the key to 
successful $21^{\text {st }}$ century management” (Korn Ferry, 2011:11). However, our results challenge the notion that CEOs "are better off being jacks-of-all-trades" (Torres, 2016: 2). Instead, our study demonstrates that CEOs with high levels of career generalism receive lower pay in their first year in office compared to those at relatively moderate levels. In making strategic career investments, executives should hence be aware of the downsides of excessive job-hopping and career mobility. Individuals who seek to realize a higher economic value - as a result of their career investments - should not only focus on acquiring a variety of knowledge from different settings, but also to retain and signal a sufficient level of career specialization and expertise. In this regard, our work provides a cautionary note stressing that the notions of generalism and specialization should be considered in conjunction in order to make optimal decisions for executive career development.

Our study is subject to some limitations which highlight avenues for future research. First, it inherently adopts a rent creation logic (Castanias \& Helfat, 1991), which suggests that executives invest in career experiences, and thus, markets reward (or penalize) them for these investments (Peng et al., 2015). We therefore attribute a degree of rationality to firms and CEO candidates when making compensation and career decisions. Yet, studies suggest that boards and remuneration committees are influenced by several behavioral factors beyond an individual's human capital (Devers et al., 2007). Future research could examine whether behavioral factors, or CEO-board relational features, affect the observed inverted U-shape relationship (Combs \& Skill, 2003). For example, future research on the CEO-board, or successor-predecessor interface can help to advance our understanding of the relationship between new CEO career background and initial compensation (Georgakakis, Heyden, Oehmichen, \& Ekanayake, in press).

Second, the use of publicly available archival data does not allow access to the actual pool of candidates that the firm considered when making a CEO selection decision. Arguably, a CEO with moderate levels of generalist career experience may also exhibit an overall higher 
likelihood of appointment to CEO positions across firms facing different conditions, and may therefore receive a larger number of job offers (Merluzzi \& Phillips, 2016). While our study provides evidence with regard to the economic value realized by new CEOs with balanced experience breadth and depth at the time of selection, future research can delve into the CEO recruitment process to examine how different levels of generalist versus specialist experience impact the likelihood of an individual's appointment to the CEO position. Such research can integrate elements from the literature on strategic recruiting and strategic staffing (Philips \& Gully, 2015), further link the notions of CEO selection and initial compensation, and thus unfold the processes through which CEO pay decisions are made.

Relatedly, the use of archival data does not allow us to observe the risk preferences of CEOs, as well as the risk considerations of firms, in order to reveal how deeply-held behavioral factors may have affected the compensation-negotiation process. In a recent study, Graffin et al., (2020) found that a key proxy for CEO values - i.e., political ideology - impacts CEOs' inherent risk preferences regarding the structure of their compensation packages. Future studies can build on the approach of Graffin et al. and integrate elements from recent research on CEO big-five personality traits (Harrison, Thurgood, Boivie, \& Pfarrer, 2019), to examine how risk perceptions of the CEO and the board of directors affect CEO initial compensation. This will help us to further unveil the role of deep level psychological factors (Hodgkinson \& Healey, $2011 ; 2018$ ) in determining CEO initial pay arrangements, and thereby bridge the micro-macro divide (Eckardt et al., 2018) in executive compensation.

Finally, our study focuses only on the initial pay received by new CEOs in their first complete fiscal year of appointment. As explained, this approach minimizes the managerialpower effects that become increasingly prominent as CEOs accumulate tenure in the firm (Chen, 2015; Graffin et al., 2020). Hence, our results are not necessarily generalizable to CEO pay in the years after appointment - when CEOs become established in their leadership positions and exert more influence on pay decisions. An interesting avenue for future research 
would therefore be to consider whether CEOs at different levels of the generalist experience continuum are more (or less) likely to accumulate power in the firm over time, and thus realize positive revisions (i.e., settling-up) in their pay after appointment (Seo et al., 2017; Wowak et al., 2011). Although the post-appointment settling up in CEO compensation is outside the scope of this study, we conducted a limited post-hoc analysis to test whether the new CEOs in our sample experience positive (or negative) revisions to their initial compensation in the years after appointment - and how this is influenced by their level of generalism. To test this, we considered whether the initial compensation received by the CEOs in our sample increased (or decreased) in their subsequent years of tenure - starting from their third year in office (Wowak et al., 2011) and ending either at the time of their exit or in the year 2017 (the final year of our studied period). Results did not provide support for an inverted curvilinear relationship between CEO generalist career experience and settling up in CEO compensation. Future studies, however, should employ samples of both newly appointed and incumbent CEOs to further delve into this relationship, and control for a more comprehensive set of variables that are likely to impact a CEO's post-appointment settling up in compensation (e.g., mergers and acquisitions pursued by the CEO over his or her years of tenure, or strategic changes that affected CEO job demands and subsequent compensation).

In sum, our study demonstrates that high levels of CEO generalist career experience do not necessarily imply higher CEO initial pay returns. This can provide a useful foundation for future studies on the effects of career background on the initial compensation of CEOs. In light of the changing nature of executive careers (Greve, Biemann, \& Ruigrok, 2015), understanding the effects of generalist experience on CEO initial pay is expected to be an area of increasing importance - for both scholars and practitioners - in the years to come. 


\section{REFERENCES}

Acemoglu, D., \& Pischke, J.-S. 1999. The Structure of Wages and Investment in General Training. Journal of Political Economy, 107(3): 539-572.

Armstrong, C.S., Barth, M.E., Jagolinzer, A.D., \& Riedl, E.J. 2010. Market reaction to the adoption of IFRS in Europe. The Accounting Review, 85(1): 31-61.

Astebro, T., \& Thompson, P. 2011. Entrepreneurs, Jacks of all trades or Hobos? Research Policy, 40(5): 637-649.

Baruch, Y., \& Vardi, Y. 2016. A Fresh Look at the Dark Side of Contemporary Careers: Toward A Realistic Discourse. British Journal of Management, 27(2): 355-372.

Bidwell, M., Won, S., Barbulascu, R., \& Mollick, E. 2015. I Used to Work for Goldman Sachs! How Firms Benefit from Organizational Status in the Market for Human Capital. Strategic Management Journal, 36: 1164-1173.

Blau, P. 1977. Inequality And Heteroeneity: A Primitive Theory Of Social Structure. New York: Free Press.

Boh W. F., Evaristo R., \& Ouderkirk A. 2014. Balancing Breadth And Depth Of Expertise For Innovation: A 3m Story. Research Policy, 43(2): 349-366.

Boivie, S., Graffin, S. D., \& Gentry, R. 2016. Understanding the Direction, Magnitude, and Joint Effects of Reputation when Multiple Actors' Reputations Collide. Academy of Management Journal, 59(1): 188-206.

Bragaw, N. A., \& Misangyi, V. F. 2017. The Value of CEO Mobility: Contextual Factors that Shape the Impact of Prior CEO Experience on Market Performance and CEO Compensation. Human Resource Management, 56(2): 243-265.

Briscoe, J. P., Hall, D. T., \& DeMuth, R. L. F. 2006. Protean and Boundaryless Careers: An Empirical Exploration. Journal of Vocational Behavior, 69(1): 30-47.

Busenbark, J. R., Krause, R., Boivie, S., \& Graffin, S. D. 2016. Toward a Configurational Perspective on the CEO: A Review and Synthesis of the Management Literature. Journal of Management, 42(1): 234-268.

Buyl, T., Boone, C., Hendriks, W., \& Matthyssens, P. 2011. Top Management Team Functional Diversity and Firm Performance: The Moderating Role Of CEO Characteristics. Journal of Management Studies, 48(1): 151-177.

Campbell, B.A., Coff, R., \& Kryscynski, D. 2012. Rethinking Sustained Competitive Advantage From Human Capital. The Academy of Management Review, 37(3): 376-395.

Cannella, A. A., \& Holcomb, T. R. 2005. A Multi-Level Analysis Of The Upper-Echelons Model. In F. Dansereau, \& F. J. Yammarino (Eds.), Multi-Level Issues in Strategy and Methods, Vol. 4: 195-237. Bingley: Emerald Group Publishing Limited.

Cannella, A. A., Park, J.-H., \& Lee, H.-U. 2008. Top Management Team Functional Background Diversity and Firm Performance: Examining The Roles Of Team Member Colocation And Environmental Uncertainty. Academy of Management Journal, 51(4): 768784.

Carpenter, M. A., Sanders, W. G., \& Gregersen, H. B. 2001. Bundling Human Capital With Organizational Context: The Impact of International Assignment Experience on Multinational Firm-Performance and CEO Pay. Academy of Management Journal, 44(3): 493-511.

Castanias, R. P., \& Helfat, C. E. 1991. Managerial Resources and Rents. Journal of Management, 17(1): 155-171.

Chen, G. 2015. Initial Compensation of New CEOs Hired in Turnaround Situations. Strategic Management Journal, 36(12): 1895-1917.

Child, J. 1974. Managerial and Organizational Factors Associated with Company Performance, Journal of Management Studies, 11(3): 175-189. 
Chung, C.-N., \& Luo, X. R. 2013. Leadership Succession and Firm Performance in an Emerging Economy: Successor Origin, Relational Embeddedness, And Legitimacy. Strategic Management Journal, 34(3): 338-357.

Collins, J. 2001. Good To Great: Why Some Companies Make The Leap... And Others Don't. New York: Harper Business.

Combs, J. G., \& Skill, M. S. 2003. Managerialist and Human Capital Explanations for Key Executive Pay Premiums: A Contingency Perspective. Academy of Management Journal, 46(1): 63-73.

European Commission. 2016. What is an SME?, Vol. 2016: European Commission. Retrieved from:https://ec.europa.eu/growth/smes/business-friendly-environment/smedefinition_en

Conyon, M. J., Peck, S. I., \& Sadler, G. V. 2001. Corporate Tournaments and Executive Compensation: Evidence from the U.K. Strategic Management Journal, 22(8): 805-815.

Conyon, M., Haas, L., Peck, S., Sadler, G., \& Zhang, Z. 2019. Do compensation consultants drive CEO pay? Evidence from UK. British Journal of Management, 30: 10-29.

Conyon, M. J., \& Murphy, K. J. 2000. The Prince and the Pauper? CEO Pay in the United States and United Kingdom, The Economic Journal, 110(467): 640-671.

Crossland, C., \& Hambrick, D. C. 2011. Differences In Managerial Discretion Across Countries: How Nation-Level Institutions Affect the Degree to Which CEOs Matter. Strategic Management Journal, 32(8): 797-819.

Crossland, C., Zyung, J., Hiller, N. J., \& Hambrick, D. C. 2014. CEO Career Variety: Effects on Firm-level Strategic and Social Novelty. Academy of Management Journal, 57(3): 652674.

Custódio, C., Ferreira, M. A., \& Matos, P. 2013. Generalists versus Specialists: Lifetime Work Experience And Chief Executive Officer Pay. Journal of Financial Economics, 108(2): 471492.

Custódio, C., Ferreira, M. A., \& Matos, P. 2019. Do General Managerial Skills Spur Innovation? Management Science, 65: 459-476.

Dane, E. 2010. Reconsidering the Trade-Off Between Expertise and Flexibility: A Cognitive Entrenchment Perspective. Academy of Management Review, 35(4): 579-603.

Datta, D. K., Guthrie, J. P., \& Rajagopalan, N. 2002. Different Industries, Different CEOs? A Study Of CEO Career Specialization. Human Resource Planning, 25(2): 14-25.

Datta, S., \& Iskandar-Datta, M. 2014. Upper-Echelon Executive Human Capital and Compensation: Generalist Vs Specialist Skills. Strategic Management Journal, 35(12): 1853-1866.

Dawson, J. F. 2014. Moderation in Management research: What, Why, When, and How. Journal of Business and Psychology, 29(1): 1-19.

Defillippi, R. J., \& Arthur, M. B. 1994. The Boundaryless Career: A Competency-based Perspective. Journal of Organizational Behavior, 15(4): 307-324.

Deloitte, 2007. IFRS-2 Share Based Payment. Retrieved from https://www.iasplus.com/en/standards/ifrs/ifrs2.

Dess, G. G., \& Beard, D. W. 1984. Dimensions Of Organizational Task Environments. Administrative Science Quarterly, 29(1): 52-73.

Devers, C. E., Cannella, A. A., Reilly, G. P., \& Yoder, M. E. 2007. Executive Compensation: A Multidisciplinary Review of Recent Developments. Journal of Management, 33(6): 10161072 .

Dragoni, L., Oh, I., Vankatwyk, P., \& Tesluk, P. 2011. Developing Executive Leaders: The Relative Contribution of Cognitive Ability, Personality, and the Accumulation of Work Experience In Predicting Strategic Thinking Competency. Personnel Psychology, 64(4): 829-864. 
Eckardt, Crocker, A., Ahn, Y., Floyd, S., Boyd, B., Hodgkinson, G., Kozlowski S. W. J., Moliterno, T., \& Starbuck, W. H. 2018. Reflections on the Micro-Macro Divide: Ideas from the Trenches and Moving Forward. Strategic Organization, 17(3): 385-402.

Falato, A., Li, D., \& Milbourn, T. 2015. Which Skills Matter in the Market for CEOs? Evidence from Pay for CEO Credentials. Management Science, 61(12): 2845-2869.

Ferguson, J.-P., \& Hasan, S. 2013. Specialization and Career Dynamics:Evidence from the Indian Administrative Service. Administrative Science Quarterly, 58(2): 233-256.

Finkelstein, S., \& Boyd, B. K. 1998. How Much Does The CEO Matter? The Role of Managerial Discretion in the Setting Of CEO Compensation. The Academy of Management Journal, 41(2): 179-199.

Finkelstein, S., Hambrick, D. C., \& Cannella, A. A. 2009. Strategic Leadership: Theory And Research On Executives, Top Management Teams, And Boards. New York: Oxford University Press.

Frydman, C., \& Jenter, D. 2010. CEO Compensation. Annual Review of Financial Economics, 2(1): 75-102.

Frydman, C., \& Saks, R. E. 2010. Executive Compensation: A New View from a Long-Term Perspective, 1936-2005. Review of Financial Studies, 23(5): 2099-2138.

Frydman, C. 2019. Rising Through the Ranks: The Evolution of the Market for Corporate Executives, 1936-2003, Management Science, 65: 4951-5448.

Fulmer, I. S. 2009. The Elephant in The Room: Labor Market Influences on CEO Compensation. Personnel Psychology, 62(4): 659-695.

Geletkanycz, M. A., Boyd, B. K., \& Finkelstein, S. 2001. The Strategic Value of CEO External Directorate Networks: Implications for CEO Compensation. Strategic Management Journal, 22(9): 889.

Georgakakis, D., Greve, P., \& Ruigrok, W. 2017. Top Management Team Faultlines and Firm Performance: Examining the CEO-TMT Interface. The Leadership Quarterly, 28(6): 741758.

Georgakakis, D., \& Ruigrok, W. 2017. CEO Succession Origin and Firm Performance: A Multilevel Study. Journal of Management Studies, 54(1): 58-87.

Georgakakis, D., Heyden, M. L., Oehmichen, J. D., \& Ekanayake, U. I. in press. Four Decades of CEO-TMT Interface Research: A Review Inspired by Role Theory. The Leadership Quarterly. doi: 10.1016/j.leaqua.2019.101354

Gibbs, J. P., \& Martin, W. T. 1962. Urbanization, Technology, and the Division of Labor: International Patterns. American Sociological Review, 27(5): 667-677.

Graffin, S. D., Hubbard, T. D., Christensen, D. M., \& Lee, E. Y. 2020. The Influence of CEO Risk Tolerance on Initial Pay Packages. Strategic Management Journal, 41(4): 788-811

Greve, P., Biemann, T., \& Ruigrok, W. 2015. Foreign Executive Appointments: A Multilevel Examination. Journal of World Business, 50(4): 674-686.

Haans, R. F. J., Pieters, C., \& He, Z.-L. 2016. Thinking About U: Theorizing and Testing Uand Inverted U-Shaped Relationships in Strategy Research. Strategic Management Journal, 37(7): 1177-1195.

Hambrick, D. C., Finkelstein, S., \& Mooney, A. C. 2005. Executive Job Demands: New Insights for Explaining Strategic Decisions and Leader Behaviors. Academy of Management Review, 30(3): 472-491.

Hambrick, D. C., \& Fukutomi, G. D. 1991. The seasons of a CEO's tenure. Academy of Management Review, 16(4), 719-742.

Harris, D., \& Helfat, C. 1997. Specificity of CEO Human Capital and Compensation. Strategic Management Journal, 18(11): 895-920.

Harrison, J.S., Thurgood, G.R., Boivie, S., \& Pfarrer, M.D. 2019. Measuring CEO personality: Developing, validating, and testing a linguistic tool. Strategic Management Journal, 40: 1316-1330. 
Haveman, H. 1992. Between a Rock and a Hard Place: Organizational Change and Performance under Conditions of Fundamental Environmental Transformation, Administrative Science Quarterly, 37(1): 48-75.

Heckman, J. 1979. Sample Specification Bias as a Selection Error. Econometrica, 47(1): 153162.

Henderson, A.D., \& Fredrickson, J.W. 1996. Information-Processing Demands as a Determinant of CEO Compensation. Academy of Management Journal, 39(3): 575-606.

Hitt, M. A., \& Tyler, B. B. 1991. Strategic Decision Models: Integrating Different Perspectives. Strategic Management Journal, 12(5): 327-351.

Hodgkinson G. P., \& Healey, M. P. 2011. Psychological Foundations of Dynamic Capabilities: Reflection and Reflexion in Strategic Management. Strategic Management Journal, 32(13): $1500-1516$.

Hodgkinson G. P., \& Healey, M. P. 2018. The Psychological Foundations of Strategic Management: Beyond Cold Cognition. In D.S., Ones, N. Anderson, C. Viswesvaran, \& H. Sinangil (eds) The Sage Handbook of Industrial, Work and Organizational Psychology. V3: Managerial Psychology and Organizational Approaches. NY: SAGE.

Judge, T. A., \& Watanabe, S. 1995. Is the Past Prologue?: A Test of Ghiselli's Hobo Syndrome. Journal of Management, 21(2): 211-229.

Kacperczyk, A., \& Younkin, P. 2017. The Paradox of Breadth: The Tension Between Experience and Legitimacy in the Transition to Entrepreneurship. Administrative Science Quarterly, 62(4): 731-764.

Kanagaretnam, K., Khokhar, A. R., \& Mawani, A. 2018. Linking Societal Trust and CEO Compensation. Journal of Business Ethics, 151(2): 295-317.

Kang, S.-C., \& Snell, S. A. 2009. Intellectual Capital Architectures and Ambidextrous Learning: A Framework for Human Resource Management. Journal of Management Studies, 46(1): 65-92.

Karaevli, A., \& Hall, D. T. T. 2006. How Career Variety Promotes the Adaptability of Managers: A Theoretical Model. Journal of Vocational Behavior, 69: 359-373.

Kim, S. 1989. Labor Specialization and the Extent of the Market. Journal of Political Economy, 97(3): 692-705.

Kleinbaum, A. M. 2012. Organizational Misfits and the Origins of Brokerage in Intrafirm Networks, Administrative Science Quarterly, 57(3): 407-452.

Kolev, K., Wiseman, R. M., \& Gomez-Mejia, L. R. 2017. Do CEOs Ever Lose? Fairness Perspective on the Allocation of Residuals between CEOs and Shareholders. Journal of Management, 43(2): 610-637.

Korn-Ferry Institute 2011. Generalism Managers Make a Come Back. Available from: https://www.kornferry.com/institute/516-generalist-managers-make-a-comeback

Lawrence, P. R., \& Lorsch, J. W. 1967. Differentiation and Integration in Complex Organizations. Administrative Science Quarterly, 12(1): 1-47.

Lazear, E. 2004. Balanced Skills and Enterpreneurship. American Economic Review, 94: 208211.

Lind, J. T., \& Mehlum, H. 2010. With or Without U? The Appropriate Test for a U-shaped Relationship, Oxford Bulletin of Economics and Statistics, 72(1), 109-118.

Lorsch, J. W., \& Maciver, E. 1989. Pawns or Potentates: Reality of America's Corporate Boards. Brighton, Massachusetts: Harvard Business Review Press.

Lungeanu, R., \& Zajac, E. J. 2019. Thinking Broad and Deep: Why Some Directors Exert an Outsized Influence on Strategic Change. Organization Science, 30(3): 489-508.

Mackey, A., Molloy, J. C., \& Morris, S. S. 2014. Scarce Human Capital in Managerial Labor Markets. Journal of Management, 40(2): 399-421.

Mansharamani, V. 2012. All Hail the Generalist, Harvard Business Review: Online publication. Retrieved from: https://hbr.org/2012/06/all-hail-the-generalist 
Merluzzi, J., \& Phillips, D. J. 2016. The Specialist Discount:Negative Returns for MBAs with Focused Profiles in Investment Banking. Administrative Science Quarterly, 61(1): 87-124.

Michel, J. G., \& Hambrick, D. C. 1992. Diversification Posture and Top Management Team Characteristics. Academy of Management Journal, 35(1): 9-37.

Miller, D., Minichilli, A., \& Corbetta, G. 2013. Is Family Leadership Always Beneficial? Strategic Management Journal, 34(5): 553-571.

Mishra, D. R. 2014. The Dark Side of CEO Ability: CEO General Managerial Skills and Cost of Equity Capital. Journal of Corporate Finance, 29: 390-409.

Munasinghe, L., \& Sigman, K. 2004. A Hobo Syndrome? Mobility, Wages, and Job Turnover. Labour Economics, 11(2): 191.

Murphy, K. J., \& Zabojnik, J. 2004. CEO Pay and Appointments: A Market-Based Explanation For Recent Trends. American Economic Review, 94(2): 192-196.

Nadkarni, S., Chen, T., \& Chen, J. 2016. The Clock is Ticking! Executive Temporal Depth, Industry Velocity, and Competitive Aggressiveness. Strategic Management Journal, 37(6): 1132-1153.

Nelson, R. R., \& Winter, S. G. 1982. An Evolutionary Theory of Economic Change. Cambridge: Harvard University Press.

Norburn, D. 1989. The Chief Executive: A Breed Apart. Strategic Management Journal, 10(1): $1-15$.

Palmer, T. B., \& Wiseman, R. M. 1999. Decoupling Risk Taking from Income Stream Uncertainty: A Holistic Model of Risk. Strategic Management Journal, 20(11): 1037-1062.

Peng, M. W., Sun, S. L., \& Markoczy, L. 2015. Human Capital and CEO Compensation During Institutional Transitions. Journal of Management Studies, 52(1): 117-147.

Phillips, J. M., \& Gully, S. M. 2015. Multilevel and Strategic Recruiting: Where have we Been, Where can we Go from Here? Journal of Management, 41(5): 1416-1445.

Rabe-Hesketh, S., \& Skrondal, A. 2008. Multilevel and Longitudinal Modeling Using Stata: STATA press.

Raudenbush, S. W., \& Bryk, A. S. 2002. Hierarchical Linear Models: Applications and Data Analysis Methods: Sage.

Salas, E., Rosen, M. A., \& DiazGranados, D. 2010. Expertise-Based Intuition and Decision Making in Organizations. Journal of Management, 36(4): 941-973.

Sasabuchi, S. 1980. A Test of a Multivariate Normal Mean with Composite Hypotheses Determined by Linear Inequalities, Biometrika, 67(2): 429-439.

Sastry, M. A. 1997. Problems and Paradoxes in a Model of Punctuated Organizational Change, Administrative Science Quarterly, 42(2): 237-275.

Sauerwald, S., van Oosterhout, J., van Essen, M., \& Peng, M. W. 2018. Proxy Advisors and Shareholder Dissent: A Cross-country Comparative Study. Journal of Management, 44(8): 3364-3394.

Seo J., Gemache, D.L., Devers, C. \& Carpenter M. 2015. The Role of CEO Relative Standing in Acquisition Behavior and CEO Pay. Strategic Management Journal, 36: 1877-1894.

Shen, W., \& Cannella Jr, A. A. 2002. Power Dynamics Within Top Management and Their Impacts on CEO Dismissal Followed by Inside Succession. Academy of Management Journal, 45(6): 1195-1206.

Shin, T. 2016. Fair Pay or Power Play? Pay Equity, Managerial Power, and Compensation Adjustments for CEOs, Journal of Management, 42(2): 419-448.

Simmons, R., \& Berri, D. J. 2009. Gains from Specialization and Free Agency: The Story from the Gridiron. Review of Industrial Organization, 34(1): 81-98.

Smith, M., \& White, M. C. 1987. Strategy, CEO Specialization, and Succession. Administrative Science Quarterly, 32(2): 263-280.

Sullivan, S. E., \& Baruch, Y. 2009. Advances in Career Theory and Research: A Critical Review and Agenda for Future Exploration. Journal of Management, 35(6): 1542-1571. 
Tallman, S., \& Li, J. 1996. Effects of International Diversity and Product Diversity on the Performance of Multinational Firms. Academy of Management Journal, 39(1): 179-196.

Tang, Y., Li, J., \& Yang, H. 2015. What I See, What I Do: How Executive Hubris Affects Firm Innovation. Journal of Management, 41(6): 1698-1723.

Torres, N. 2016. Generalists Get Better Job Offers than Specialists. Harvard Business Review, 94: $30-31$.

Tuggle, C. S., Sirmon, D. G., \& Reutzel, C. R. 2010. Commanding Board of Director Attention: Investigating How Organizational Performance and CEO Duality Affect Board Members' Attention to Monitoring, Strategic Management Journal, 31(9): 946-968.

Tushman, M.L., D.A. \& Nadler. 1978. Information Processing as an Integrating Concept in Organizational Design. Academy of Management Review, 3(3): 613-624.

van Essen, M., Otten, J., \& Carberry, 2015. Assessing Managerial Power Theory: A MetaAnalytic Approach to Understanding the Determinants of CEO Compensation. Journal of Management, 41: 164-202.

van Essen, M., Heugens, P. P., Otten, J., \& van Oosterhout, J. 2012. An Institution-based View of Executive Compensation: A Multilevel Meta-analytic Test. Journal of International Business Studies, 43(4): 396-423.

Wowak, A. J., Hambrick, D. C., \& Henderson A. D. 2011. Do CEOs Encounter Within-Tenure Settling Up? A Multiperiod Perspective on Executive Pay and Dismissal. Academy of Management Journal, 54(4): 719-739.

Zhang, Y., \& Rajagopalan, N. 2004. When the Known Devil is Better than the Unknown God: An Empirical Study on the Antecedents and Consequencesof Relay Successions. Academy of Management Journal, 47(4): 483-500.

Zorn, M. L., Shropshire, C., Martin, J. A., Combs, J. G., \& Ketchen, D. J. 2017. Home Alone: The Effects of Lone-Insider Boards on CEO Pay, Financial Misconduct, and Firm Performance. Strategic Management Journal, 38(13): 2623-2646.

Zuckerman, E.W. Kim T.Y., Ukanwa K., \& Rittmann, J. 2003. Robust Identities or Nonentities? Typecasting in the Feature-Film Labor Market. American Journal of Sociology, 108(5): 1018-1073. 
TABLE 1

Descriptive Statistics and Correlations (continued next page)

\begin{tabular}{|c|c|c|c|c|c|c|c|c|c|c|c|c|c|c|c|c|}
\hline Variables & $x^{-}$ & SD & 1 & 2 & 3 & 4 & 5 & 6 & 7 & 8 & 9 & 10 & 11 & 12 & 13 & 14 \\
\hline $\begin{array}{l}\text { 1. CEO total init. } \\
\text { compensation }^{\mathrm{a}}\end{array}$ & 14.48 & 0.87 & $\sim$ & & & & & & & & & & & & & \\
\hline 2. Ind. complexity & 0.87 & 0.11 & 0.13 & $\sim$ & & & & & & & & & & & & \\
\hline 3. Ind. munificence & 0.04 & 0.03 & -0.04 & -0.41 & $\sim$ & & & & & & & & & & & \\
\hline 4. Ind. dynamism & 0.08 & 0.04 & -0.02 & -0.20 & -0.53 & $\sim$ & & & & & & & & & & \\
\hline 5. CEO career length & 26.50 & 6.08 & 0.19 & -0.13 & 0.01 & 0.14 & $\sim$ & & & & & & & & & \\
\hline 6. Board independence & 0.86 & 0.14 & -0.21 & 0.06 & 0.02 & 0.02 & -0.08 & $\sim$ & & & & & & & & \\
\hline 7. TMT firm tenure & 12.09 & 7.04 & 0.19 & -0.17 & 0.16 & -0.00 & 0.08 & -0.12 & $\sim$ & & & & & & & \\
\hline 8. Firm size (sales) ${ }^{\mathrm{a}}$ & 8.44 & 1.79 & 0.61 & -0.02 & -0.20 & 0.11 & 0.17 & -0.11 & 0.33 & $\sim$ & & & & & & \\
\hline 9. Degree of internati. & 0.54 & 0.32 & 0.24 & -0.11 & 0.42 & -0.08 & 0.09 & 0.08 & 0.21 & 0.15 & $\sim$ & & & & & \\
\hline 10. Firm diversificat. & 0.96 & 0.50 & 0.20 & 0.01 & -0.04 & 0.03 & 0.03 & 0.18 & 0.21 & 0.35 & 0.10 & $\sim$ & & & & \\
\hline 11. Country CEO disc. & 5.05 & 0.67 & 0.04 & -0.03 & -0.07 & 0.06 & 0.22 & -0.51 & -0.04 & -0.04 & 0.02 & -0.07 & $\sim$ & & & \\
\hline 12. Prior perf. decl. & 0.58 & 7.43 & 0.03 & -0.03 & 0.04 & 0.14 & 0.08 & 0.08 & -0.03 & -0.11 & 0.15 & -0.05 & 0.03 & $\sim$ & & \\
\hline 13. CEO MBA & 0.19 & 0.40 & 0.05 & 0.04 & 0.03 & -0.00 & -0.09 & -0.02 & -0.02 & 0.01 & 0.07 & 0.17 & 0.22 & 0.02 & $\sim$ & \\
\hline 14. CEO duality & 0.04 & 0.20 & -0.03 & -0.00 & -0.08 & 0.05 & 0.28 & -0.07 & -0.03 & 0.04 & -0.07 & 0.01 & 0.04 & 0.00 & -0.10 & $\sim$ \\
\hline 15. Fast-track career & -0.34 & 3.89 & 0.12 & -0.04 & -0.08 & 0.10 & 0.43 & -0.01 & -0.01 & 0.12 & -0.02 & -0.01 & 0.10 & 0.12 & 0.05 & 0.05 \\
\hline 16. CEO ind. spec.exp. & 0.86 & 0.35 & 0.11 & 0.09 & -0.11 & 0.08 & 0.05 & -0.09 & 0.04 & 0.04 & -0.04 & 0.03 & 0.05 & -0.02 & -0.02 & -0.06 \\
\hline 17. CEO funct.exp var. & 0.52 & 0.23 & -0.08 & 0.16 & -0.14 & -0.05 & -0.11 & 0.13 & -0.05 & -0.08 & -0.11 & -0.04 & -0.11 & -0.04 & 0.11 & -0.09 \\
\hline 18. Prior CEO exp. & 0.13 & 0.33 & 0.02 & 0.01 & 0.02 & -0.08 & 0.09 & -0.08 & -0.01 & 0.03 & 0.02 & 0.01 & 0.03 & -0.05 & -0.03 & 0.15 \\
\hline 19. Career gen. manag. & 0.17 & 0.20 & -0.12 & -0.06 & 0.06 & -0.10 & -0.01 & 0.00 & -0.15 & -0.15 & -0.12 & -0.10 & -0.13 & -0.07 & -0.07 & 0.14 \\
\hline 20. Outside CEO orig. & 0.44 & 0.50 & -0.14 & 0.04 & 0.08 & -0.13 & -0.05 & 0.02 & -0.25 & -0.25 & -0.16 & -0.05 & -0.02 & -0.05 & 0.14 & 0.02 \\
\hline 21. CEO gender & 0.02 & 0.14 & 0.00 & -0.08 & 0.03 & -0.07 & -0.07 & -0.04 & 0.00 & 0.04 & -0.05 & 0.02 & 0.11 & -0.17 & 0.11 & -0.03 \\
\hline 22. Pred. retirement & 0.13 & 0.33 & -0.07 & 0.08 & -0.02 & -0.05 & -0.10 & 0.02 & 0.09 & 0.08 & 0.02 & 0.10 & -0.14 & -0.20 & -0.11 & -0.08 \\
\hline 23. Pred. tenure & 7.87 & 5.05 & -0.10 & -0.03 & 0.09 & -0.12 & -0.12 & 0.01 & 0.20 & -0.04 & 0.04 & -0.03 & -0.00 & 0.03 & -0.02 & -0.12 \\
\hline 24. Pred. hiring mode & 0.38 & 0.49 & -0.10 & 0.17 & -0.01 & -0.10 & -0.16 & 0.05 & -0.23 & -0.26 & -0.06 & -0.11 & -0.12 & -0.07 & -0.07 & -0.06 \\
\hline $\begin{array}{l}\text { 25. Legitim. in prior } \\
\text { career exp }\end{array}$ & 0.92 & 0.94 & 0.30 & 0.05 & -0.05 & 0.05 & 0.07 & -0.10 & 0.03 & 0.29 & 0.06 & 0.19 & 0.03 & 0.01 & 0.05 & -0.04 \\
\hline $\begin{array}{l}\text { 26.CEO generalist } \\
\text { exp. }\end{array}$ & 0.78 & 0.49 & -0.06 & 0.12 & 0.03 & -0.12 & -0.00 & -0.00 & -0.25 & -0.18 & -0.07 & 0.06 & -0.04 & -0.11 & -0.04 & 0.01 \\
\hline $\begin{array}{l}\text { 27.CEO generalist } \\
\text { exp. }^{2}\end{array}$ & 0.84 & 0.71 & -0.09 & 0.10 & 0.07 & -0.14 & 0.02 & -0.02 & -0.22 & -0.19 & -0.04 & 0.03 & -0.02 & -0.13 & -0.03 & 0.03 \\
\hline
\end{tabular}


TABLE 1

Descriptive Statistics and Correlations (continued)

\begin{tabular}{|c|c|c|c|c|c|c|c|c|c|c|c|c|c|}
\hline Variables & 15 & 16 & 17 & 18 & 19 & 20 & 21 & 22 & 23 & 24 & 25 & 26 & 27 \\
\hline 15. Fast- track career & $\sim$ & & & & & & & & & & & & \\
\hline 16. CEO ind. spec.exp. & 0.00 & $\sim$ & & & & & & & & & & & \\
\hline 17. CEO funct. exp var. & -0.13 & 0.09 & $\sim$ & & & & & & & & & & \\
\hline 18. Prior CEO exp. & -0.45 & -0.02 & 0.18 & $\sim$ & & & & & & & & & \\
\hline 19. Career gen manag. & -0.12 & -0.14 & 0.19 & 0.31 & $\sim$ & & & & & & & & \\
\hline 20. Outside CEO orig. & -0.08 & -0.34 & 0.21 & 0.21 & 0.25 & $\sim$ & & & & & & & \\
\hline 21. CEO gender & 0.06 & 0.06 & -0.03 & -0.05 & 0.01 & -0.06 & $\sim$ & & & & & & \\
\hline 22. Pred. retirement & -0.08 & 0.11 & 0.09 & 0.04 & -0.06 & -0.09 & -0.05 & $\sim$ & & & & & \\
\hline 23. Pred. tenure & -0.02 & -0.02 & 0.05 & -0.09 & -0.10 & -0.16 & 0.05 & 0.26 & $\sim$ & & & & \\
\hline 24. Pred. hiring mode & -0.14 & 0.02 & 0.05 & 0.08 & -0.01 & 0.17 & -0.11 & 0.08 & -0.00 & $\sim$ & & & \\
\hline $\begin{array}{l}25 . \text { Legitim. in prior } \\
\text { career exp }\end{array}$ & -0.01 & -0.00 & 0.05 & 0.13 & -0.09 & 0.16 & -0.03 & -0.03 & -0.04 & -0.04 & $\sim$ & & \\
\hline 26.CEO generalist exp. & -0.09 & 0.05 & 0.07 & 0.15 & 0.16 & 0.19 & -0.00 & -0.07 & -0.04 & 0.19 & 0.20 & $\sim$ & \\
\hline 27.CEO generalist exp. ${ }^{2}$ & -0.09 & 0.06 & 0.04 & 0.13 & 0.16 & 0.16 & -0.00 & -0.06 & -0.08 & 0.15 & 0.18 & 0.96 & $\sim$ \\
\hline
\end{tabular}


TABLE 2

HLM Analysis with CEO Total Compensation as Dependent Variable ${ }^{\text {a }}$

\begin{tabular}{|c|c|c|c|c|c|c|c|c|c|c|c|c|c|c|c|c|c|c|}
\hline & \multicolumn{3}{|c|}{ Model 1} & \multicolumn{3}{|c|}{ Model 2} & \multicolumn{3}{|c|}{ Model 3} & \multicolumn{3}{|c|}{ Model 4} & \multicolumn{3}{|c|}{ Model 5} & \multicolumn{3}{|c|}{ Model 6} \\
\hline & Coef & Std.Err & P-value & Coef & Std.Err & P-value & Coef & Std.Err & P-value & Coef & Std.Err & P-value & Coef & Std.Err & P-value & Coef & Std.Err & P-value \\
\hline Constant & 13.52 & 0.28 & 0.000 & 13.39 & 0.30 & 0.000 & 12.86 & 0.35 & 0.000 & 13.40 & 0.31 & 0.000 & 13.39 & 0.29 & 0.000 & 12.95 & 0.35 & 0.000 \\
\hline Inverse Mills ratio & 0.19 & 0.12 & 0.111 & 0.20 & 0.12 & 0.106 & 0.23 & 0.12 & 0.067 & 0.19 & 0.13 & 0.150 & 0.21 & 0.13 & 0.100 & 0.23 & 0.13 & 0.087 \\
\hline Industry complexity & 1.60 & 0.52 & 0.002 & 1.56 & 0.49 & 0.002 & 1.36 & 0.49 & 0.006 & 1.58 & 0.49 & 0.001 & 2.28 & 0.56 & 0.000 & 1.93 & 0.50 & 0.000 \\
\hline Industry munificence & 3.66 & 2.29 & 0.110 & 3.56 & 2.22 & 0.108 & 3.54 & 2.25 & 0.116 & 4.42 & 2.27 & 0.051 & 3.61 & 2.22 & 0.104 & 4.11 & 2.37 & 0.083 \\
\hline Industry dynamism & 0.16 & 1.19 & 0.893 & -0.13 & 1.18 & 0.910 & -0.17 & 1.23 & 0.887 & 0.17 & 1.16 & 0.885 & 0.00 & 1.16 & 0.997 & 0.11 & 1.24 & 0.929 \\
\hline CEO career length & 0.01 & 0.01 & 0.142 & 0.01 & 0.01 & 0.115 & 0.01 & 0.01 & 0.192 & 0.01 & 0.01 & 0.174 & 0.01 & 0.01 & 0.204 & 0.01 & 0.01 & 0.311 \\
\hline Board independence & -1.42 & 0.41 & 0.001 & -1.41 & 0.39 & 0.000 & -1.36 & 0.34 & 0.000 & -1.33 & 0.39 & 0.001 & -1.42 & 0.40 & 0.000 & -1.32 & 0.34 & 0.000 \\
\hline TMT firm tenure & -0.00 & 0.01 & 0.950 & 0.00 & 0.01 & 0.851 & 0.00 & 0.01 & 0.694 & -0.00 & 0.01 & 0.966 & 0.00 & 0.01 & 0.800 & 0.00 & 0.01 & 0.784 \\
\hline Firm size (sales)b & 0.29 & 0.04 & 0.000 & 0.28 & 0.04 & 0.000 & 0.28 & 0.04 & 0.000 & 0.29 & 0.04 & 0.000 & 0.28 & 0.04 & 0.000 & 0.28 & 0.04 & 0.000 \\
\hline Degree of internationalization & 0.45 & 0.17 & 0.007 & 0.48 & 0.16 & 0.003 & 0.47 & 0.15 & 0.002 & 0.52 & 0.17 & 0.002 & 0.46 & 0.16 & 0.005 & 0.49 & 0.16 & 0.003 \\
\hline Firm diversification & -0.00 & 0.10 & 0.987 & -0.03 & 0.09 & 0.749 & 0.44 & 0.15 & 0.004 & -0.05 & 0.09 & 0.596 & -0.01 & 0.09 & 0.897 & 0.38 & 0.17 & 0.021 \\
\hline Country CEO discretion score & -0.12 & 0.08 & 0.149 & -0.11 & 0.08 & 0.157 & -0.12 & 0.07 & 0.098 & -0.10 & 0.07 & 0.181 & -0.09 & 0.07 & 0.208 & -0.11 & 0.07 & 0.130 \\
\hline Prior Performance decline & 0.01 & 0.00 & 0.066 & 0.01 & 0.00 & 0.082 & 0.01 & 0.00 & 0.050 & -0.03 & 0.01 & 0.039 & 0.01 & 0.00 & 0.073 & -0.02 & 0.01 & 0.193 \\
\hline CEO MBA & 0.09 & 0.12 & 0.447 & 0.11 & 0.12 & 0.334 & 0.11 & 0.12 & 0.338 & 0.07 & 0.11 & 0.532 & 0.08 & 0.11 & 0.436 & 0.07 & 0.11 & 0.548 \\
\hline CEO duality & -0.25 & 0.20 & 0.224 & -0.20 & 0.20 & 0.306 & -0.17 & 0.20 & 0.390 & -0.10 & 0.22 & 0.640 & -0.23 & 0.20 & 0.249 & -0.12 & 0.22 & 0.575 \\
\hline Fast-track career & 0.01 & 0.01 & 0.493 & 0.01 & 0.01 & 0.614 & 0.01 & 0.01 & 0.474 & 0.01 & 0.01 & 0.502 & 0.01 & 0.01 & 0.488 & 0.01 & 0.01 & 0.315 \\
\hline CEO industry specific experience & 0.18 & 0.11 & 0.094 & 0.19 & 0.10 & 0.070 & 0.17 & 0.11 & 0.131 & 0.21 & 0.11 & 0.050 & 0.20 & 0.11 & 0.055 & 0.21 & 0.12 & 0.078 \\
\hline CEO functional experience variety & 0.03 & 0.16 & 0.843 & -0.01 & 0.17 & 0.973 & -0.02 & 0.17 & 0.907 & -0.07 & 0.17 & 0.694 & 0.02 & 0.17 & 0.925 & -0.04 & 0.16 & 0.791 \\
\hline Prior CEO experience & -0.05 & 0.12 & 0.696 & -0.08 & 0.11 & 0.494 & -0.05 & 0.12 & 0.703 & -0.08 & 0.12 & 0.474 & -0.08 & 0.12 & 0.517 & -0.05 & 0.12 & 0.670 \\
\hline Career general management & 0.22 & 0.19 & 0.241 & 0.27 & 0.18 & 0.123 & 0.10 & 0.20 & 0.604 & 0.30 & 0.18 & 0.096 & 0.29 & 0.18 & 0.114 & 0.17 & 0.20 & 0.417 \\
\hline Outside CEO origin & 0.02 & 0.09 & 0.860 & 0.00 & 0.09 & 0.961 & -0.00 & 0.09 & 0.956 & 0.00 & 0.09 & 0.959 & -0.02 & 0.09 & 0.823 & -0.02 & 0.08 & 0.793 \\
\hline CEO gender & 0.11 & 0.21 & 0.614 & 0.09 & 0.19 & 0.648 & 0.10 & 0.20 & 0.595 & -0.11 & 0.26 & 0.659 & -0.01 & 0.18 & 0.938 & -0.12 & 0.22 & 0.582 \\
\hline Predecessor retirement & -0.27 & 0.13 & 0.030 & -0.23 & 0.14 & 0.092 & -0.21 & 0.13 & 0.112 & -0.24 & 0.14 & 0.074 & -0.25 & 0.13 & 0.057 & -0.23 & 0.12 & 0.059 \\
\hline Predecessor tenure & -0.01 & 0.01 & 0.636 & -0.01 & 0.01 & 0.407 & -0.01 & 0.01 & 0.308 & -0.01 & 0.01 & 0.499 & -0.01 & 0.01 & 0.373 & -0.01 & 0.01 & 0.348 \\
\hline Legitimacy in prior career experience & 0.07 & 0.05 & 0.175 & 0.07 & 0.05 & 0.117 & 0.09 & 0.04 & 0.050 & 0.07 & 0.05 & 0.140 & 0.07 & 0.05 & 0.147 & 0.08 & 0.05 & 0.095 \\
\hline Predecessor hiring mode & 0.07 & 0.10 & 0.471 & 0.04 & 0.10 & 0.655 & 0.05 & 0.10 & 0.653 & 0.01 & 0.09 & 0.894 & 0.05 & 0.10 & 0.622 & 0.02 & 0.10 & 0.812 \\
\hline CEO generalist experience & 0.04 & 0.11 & 0.739 & 0.72 & 0.34 & 0.035 & 1.93 & 0.56 & 0.001 & 0.68 & 0.32 & 0.034 & 0.65 & 0.32 & 0.042 & 1.77 & 0.59 & 0.003 \\
\hline $\mathrm{CEO}$ generalist experience ${ }^{\wedge}$ & & & & -0.48 & 0.21 & 0.020 & -1.02 & 0.36 & 0.005 & -0.46 & 0.20 & 0.023 & -0.44 & 0.19 & 0.022 & -0.97 & 0.38 & 0.011 \\
\hline \multicolumn{19}{|l|}{ Level 1-2 Interaction } \\
\hline Firm diversification $\mathrm{x}$ CEO generalist experience & & & & & & & -1.22 & 0.49 & 0.012 & & & & & & & -1.15 & 0.53 & 0.031 \\
\hline Firm diversification $x$ CEO generalist experience ${ }^{\wedge}$ & & & & & & & 0.54 & 0.34 & 0.114 & & & & & & & 0.55 & 0.36 & 0.124 \\
\hline Prior Perf. Decline x CEO generalist experience & & & & & & & & & & 0.13 & 0.03 & 0.000 & & & & 0.10 & 0.04 & 0.007 \\
\hline Prior Perf. Decline x CEO generalist experience ${ }^{\wedge}$ & & & & & & & & & & -0.07 & 0.02 & 0.001 & & & & -0.06 & 0.02 & 0.013 \\
\hline \multicolumn{19}{|l|}{ Level 1-3 Interaction } \\
\hline Industry complexity x CEO generalist experience & & & & & & & & & & & & & -4.63 & 2.34 & 0.048 & -4.16 & 2.45 & 0.090 \\
\hline Industry complexity $\mathrm{x} \mathrm{CEO}$ generalist experience ${ }^{\wedge} 2$ & & & & & & & & & & & & & 3.38 & 1.34 & 0.012 & 3.19 & 1.46 & 0.029 \\
\hline Deviance $:-2 * e(l l)$ & 348.3 & & & 343.7 & & & 335.6 & & & 336.6 & & & 340.8 & & & 328.4 & & \\
\hline
\end{tabular}

Notes: Individual level: N=197; Firm level: N= 166; Industry Level: N=43; a: Year dummies are included but not shown; b: natural logarithm 


\section{Figure 1: Effect of CEO generalist experience on CEO initial pay}

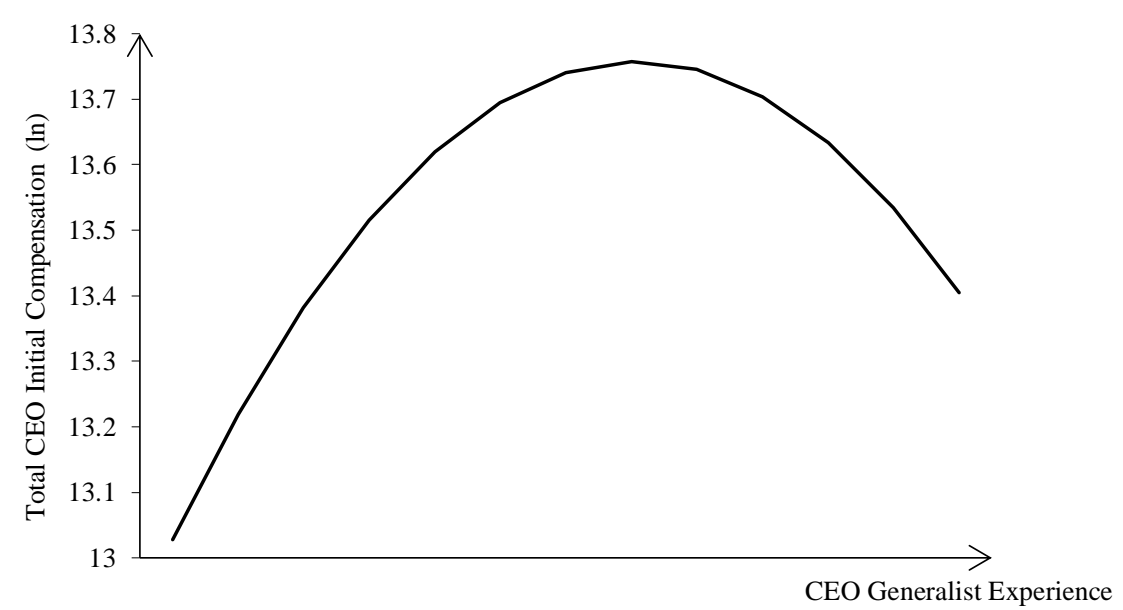

Figure 3: Moderating effect of Industry Complexity

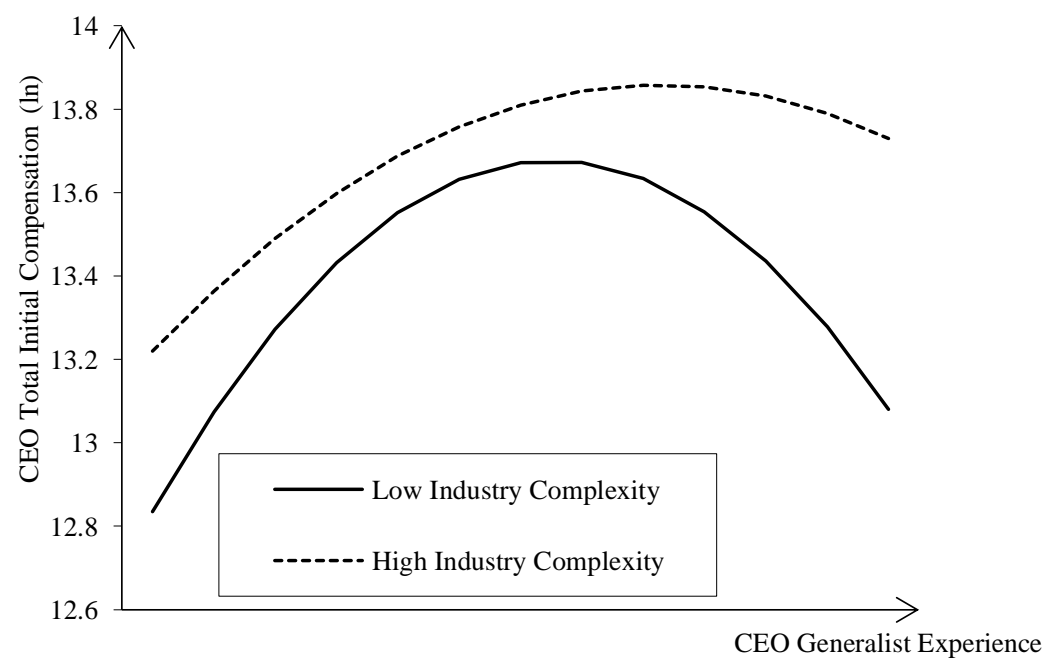

Figure 2: Moderating effect of Prior Performance Decline

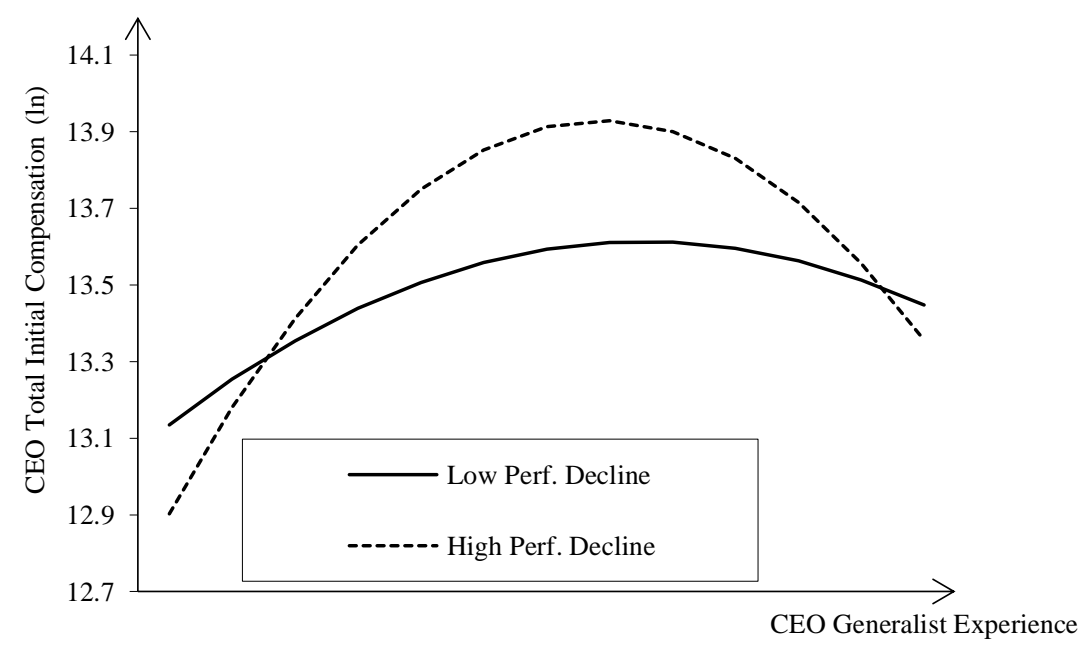


